NBER WORKING PAPER SERIES

\title{
REGULATIONS, MARKET STRUCTURE, INSTITUTIONS, AND THE COST OF FINANCIAL INTERMEDIATION
}

\author{
Asli Demirgüç-Kunt \\ Luc Laeven \\ Ross Levine \\ Working Paper 9890 \\ http://www.nber.org/papers/w9890
NATIONAL BUREAU OF ECONOMIC RESEARCH 1050 Massachusetts Avenue
Cambridge, MA 02138
July 2003

\begin{abstract}
We thank Allan Berger, John Boyd, Gianni De Nicolo, Carola Schenone, Phil Strahan, Andrew Winton, seminar participants at the University of Minnesota, the World Bank, and the Cleveland Federal Reserve Bank, and an anonymous referee for very helpful discussions and comments. This paper's findings, interpretations, and conclusions are entirely those of the authors and do not necessarily represent the views of the World Bank, its Executive Directors, or the countries they represent. The views expressed herein are those of the authors and not necessarily those of the National Bureau of Economic Research.
\end{abstract}

(C2003 by Asli Demirgüç-Kunt, Luc Laeven, and Ross Levine. All rights reserved. Short sections of text, not to exceed two paragraphs, may be quoted without explicit permission provided that full credit, including (C) notice, is given to the source. 
Regulations, Market Structure, Institutions, and the Cost of Financial Intermediation Asli Demirgüç-Kunt, Luc Laeven, and Ross Levine

NBER Working Paper No. 9890

July 2003

JEL No. G21, G28, O16

\section{ABSTRACT}

This paper examines the impact of bank regulations, market structure, and national institutions on bank net interest margins and overhead costs using data on over 1,400 banks across 72 countries while controlling for bank-specific characteristics. The data indicate that tighter regulations on bank entry and bank activities boost the cost of financial intermediation. Inflation also exerts a robust, positive impact on bank margins and overhead costs. While concentration is positively associated with net interest margins, this relationship breaks down when controlling for regulatory impediments to competition and inflation. Furthermore, bank regulations become insignificant when controlling for national indicators of economic freedom or property rights protection, while these institutional indicators robustly explain cross-bank net interest margins and overhead expenditures. Thus, bank regulations cannot be viewed in isolation; they reflect broad, national approaches to private property and competition.

$\begin{array}{lll}\text { Asli Demirgüç-Kunt } & \text { Luc Laeven } & \text { Ross Levine } \\ \text { World Bank } & \text { World Bank } & \text { Carlson School } \\ \text { Washington, DC 20433 } & \text { Washington, DC 20433 } & \text { of Management } \\ \text { ademirguckunt@worldbank.org } & \text { llaeven@worldbank.org } & \text { University of Minnesota } \\ & & \text { Minneapolis, MN 55455 } \\ & & \text { and NBER } \\ & & \text { rlevine@csom.umn.edu }\end{array}$




\section{Introduction}

This paper assesses the impact of bank regulations, market structure, and national institutions on the cost of intermediation as measured by bank net interest margins and bank overhead expenditures. Banks mobilize and allocate society's savings and the efficiency with which they intermediate capital has substantive repercussions on economic performance (Jayaratne and Strahan, 1996; Demirguc-Kunt and Maksimovic, 1998; Rajan and Zingales, 1998; Wurgler, 2000; Beck, Levine, and Loayza, 2000; and Levine, Loayza, and Beck, 2000). Thus, research on the determinants of the cost of intermediation will naturally enter the policy dialogue (Group of Ten, 2001; Bank for International Settlements, 2001; and International Monetary Fund, 2001).

Theory provides conflicting predictions about the relationships among regulations, concentration, institutions, and bank efficiency. Many of these differences arise because of differing beliefs about the causes of bank concentration. One common view holds that regulatory impediments to competition and monopolistic power create an environment in which a few powerful banks stymie competition with deleterious implications for efficiency. From this perspective, high concentration is a useful signal of an uncompetitive and hence inefficient market. Alternatively, the "efficient-structure" theory argues that more efficient banks have lower costs and garner greater market share (Demsetz, 1973; Pelzman, 1977). ${ }^{1}$ From this perspective, competitive environments may produce concentrated and efficient banking systems. Finally, a growing literature holds that some countries have institutions that restrict competition to protect a powerful elite (Engerman and Sokoloff, 1997; Acemoglu, et al., 2001; Haber et al.,

\footnotetext{
${ }^{1}$ Scale economies may also drive banking to a monopolistic structure (Diamond, 1984; Boyd and Prescott, 1986).
} 
2003). ${ }^{2}$ According to this "institutions" view, bank regulations and concentration reflect broader institutional characteristics rather than representing independent determinants of bank efficiency. To assess the impact of bank regulations, the usefulness of concentration as a signal, and to understand the role of national institutions in shaping regulations and market structure, one needs to examine individual banks operating in distinct regulatory and institutional environments.

This is the first study to examine the influence of bank regulations, concentration, and institutional development on bank margins and overhead expenditures across a broad cross section of countries while controlling for bank specific factors and cross-country differences in macroeconomic and financial sector conditions. We use bank-level data across 72 countries and over 1,400 banks. This sample includes great diversity in terms of the cost of financial intermediation, other bank characteristics, bank regulations, macroeconomic and financial conditions, and national institutions. New data on bank regulations allow us to contribute to the public policy debate and help distinguish among theoretical models by studying the regulatory, market structure, and institutional determinants of the cost of intermediation.

We examine two dependent variables to gauge the cost of financial intermediation: the net interest margin and overhead expenditures. The net interest margin equals interest income minus interest expense divided by interest-bearing assets. The net interest margin measures the gap between what the bank pays savers and what the bank receives from borrowers. Thus, the net interest margin focuses on the traditional borrowing and lending operations of the bank. The overhead expenditure ratio is computed by dividing bank overhead costs by the total assets of the bank. Cost inefficiencies and market power may be reflected in high overhead costs. Though subject to measurement problems discussed below, the net interest margin and overhead

\footnotetext{
${ }^{2}$ For an analysis of the politics fostering bank deregulation and policies, see Kroszner and Strahan (1999) and Rajan and Zingales (2003).
} 
expenditures reflect the pure operational efficiency of the bank and the competitive nature of the banking market. For brevity, we focus on the results using bank net interest margins because the two dependent variables yield remarkably similar findings.

To assess and interpret accurately the relationship between the cost of intermediation and regulations, concentration, and national institutions, we need to account for the fact that banks differ within countries and banks differ systematically across countries. At a country-level, we control for differences in what the term "bank" means. That is, we control for differences in banks' ability to conduct securities market, insurance, and real estate operations, and whether banks can own nonfinancial firms. We also control for the degree of state-ownership of commercial banks. At the bank-specific level, we control for bank size, the liquidity of bank assets, bank equity relative to its assets, the degree to which the bank raises income through fees and commissions, the standard deviation of each bank's return on assets, and the market share of each bank. Although the relationships between bank margins and these bank-specific variables are independently informative as we discuss below, our focus is on the impact of bank regulations, concentration, and national institutions on bank margins. Thus, we primarily use these bank-specific variables to control for country-level and bank-level differences that might confound the inferences that we draw on bank regulations, concentration, and national institutions.

To examine bank regulations, we exploit Barth, Caprio, and Levine's (2001b, 2003) new database. We focus on regulations concerning bank entry, reserve requirements, restrictions on bank activities, and an overall index of regulatory restrictions on banks. Thus, we use an assortment of information on the degree to which regulations may impede bank operations and competition. 
To study the impact of bank concentration on the cost of intermediation, we primarily use the fraction of assets held by the three largest banks. We confirm our results using alternative measures of bank concentration. If bank concentration reflects only regulatory restrictions on competition and our data fully measure regulatory restrictions, then any positive relationship between bank margins and concentration should vanish when controlling for regulatory restrictions. If concentration reflects regulatory restrictions and efficient-structure forces, then we may actually find a negative coefficient on concentration after controlling for regulatory impediments to competition.

We also analyze the impact of institutions on the cost of intermediation using indicators of property rights protection and the degree of economic freedom. Controlling for institutions permits us to assess whether bank regulatory policies influence bank margins and overhead costs beyond broad national approaches to competition. If bank regulatory policies reflect national approaches to competition in general and our data comprehensively measure institutions, then any association between regulations and the cost of intermediation should disappear when we control for the overall level of institutional development governing property rights and competition.

To assess the robustness of the links between the cost of financial intermediation and regulations, market structure, and institutions, we control for various theories of the role of macroeconomic influences on bank margins and overhead expenditures. Huybens and Smith (1999), for instance, stress that inflation exacerbates informational asymmetries and therefore leads to larger interest margins. We examine this prediction. Also, we control for the level of equity market development since competition from other segments of the financial system may influence the cost of intermediation. Furthermore, since business-cycle fluctuations and 
government ownership of banks may influence the pricing of loans and deposits, we include GDP growth and the extent of state-ownership of banks in the analyses.

There are at least three important reasons for examining a broad cross-section of countries in assessing the relationship between the cost of intermediation and bank regulations, bank concentration, and national institutions. First, although past research focuses on the U.S., the U.S. banking industry is unrepresentative. For example, the U.S. has over 23,000 banking institutions, which is large even compared to Japan $(4,635)$, Germany $(3,509)$, and France $(547){ }^{3}$ Also, the U.S. has very developed financial, legal, and regulatory systems, few state-owned banks, and strong protection of private property, but these features do not hold in many countries. Thus, it is important to look beyond the U.S. and to control for differences in institutional development in drawing inferences about the impact of banking structure and regulations on net interest margins. Second, existing work focuses on concentration as a signal of competitiveness, but concentration per se is difficult to interpret. Theory suggests that concentration reflects many factors, including regulatory restrictions on competition, efficientstructure forces, and market power by banks. ${ }^{4}$ By controlling for regulatory restrictions on bank competition, bank-specific characteristics, and the overall institutional environment, we narrow the range of factors for which concentration proxies. This can only be done in a cross-country context. Thus, while not fully resolving the interpretational problem with bank concentration, we obtain more informative measures of the impact of bank concentration on net interest margins

\footnotetext{
${ }^{3}$ These statistics are for 1996 and are taken from Berger, Demsetz, and Strahan (1999, Table 5).

${ }^{4}$ While a few influential papers examine the relationship between concentration and efficiency outside of the U.S., they do not control for cross-country differences in regulatory restrictions on bank competition.

Similar to the U.S. studies, the non-U.S. studies also tend to produce ambiguous results on the concentrationefficiency relationship (Goldberg and Rai, 1996; Lloyd-Williams, Moyneux, and Thornton, 1994). Using crosscountry banking data, Demirguc-Kunt and Huizinga (1999) find little evidence that bank concentration has any effect on bank profitability or margins. In a cross-country, cross-industry study Cetorelli and Gambera (2001) show that banking sector concentration exerts a depressing effect on overall economic growth, though it promotes the
} 
across countries. Finally, although Jayaratne and Strahan $(1996,1998)$ and Stiroh and Strahan (2003) examine the impact of the deregulation of branching restrictions in the United States, we provide estimates of the impact of numerous regulations on bank efficiency across 72 countries while controlling for bank concentration, national economic and banking conditions, and crosscountry differences in a range of institutional features.

Our research is related to an enormous literature on bank structure and efficiency. We focus on a few key papers that motivate our approach and refer readers to more comprehensive reviews (Bank for International Settlements, 2001; Berger and Mester, 1997; Berger, Demsetz, and Strahan, 1999; Boyd and Graham, 1991, 1998; Group of Ten, 2001; and International Monetary Fund, 2001). Most of the empirical evidence on banking structure and efficiency examines the U.S. banking industry, producing generally ambiguous results. Some evidence suggests that banks in highly concentrated local markets have larger overhead expenditures, charge higher rates on loans, pay lower rates on deposits, and are slower to reduce rates in response to Federal Reserve reductions in interest rates than banks in less concentrated markets (Berger and Hannan, 1989, 1998; Hannan and Berger, 1991; and Neumark and Sharpe, 1992). Others disagree. Smirlock (1985) and Graddy and Kyle (1979) find that interest rate spreads are narrower in concentrated banking systems, while Whitehead $(1977,1978)$ and Keeley and Zimmerman (1985) report more mixed results. Although Berger, Saunders, Scalise, and Udell (1998) find that the best performing banks are generally not located in highly concentrated markets and Rajan and Peterson (1995) find that firms are less credit constrained in more concentrated banking markets, other researchers do not find unambiguous evidence that mergers and acquisitions that increase bank concentration systematically lower deposit rates and increase

growth of industries that depend heavily on external finance. See Claessens and Laeven (2004) on the factors driving cross-country differences in bank competition. 
bank profitability (Prager and Hannan, 1999; Simons and Stavins, 1998; Berger and Humphrey, 1992; Pilloff, 1996; and Petersen and Rajan, 1994). Berger (1995) concludes that the relationship between bank concentration and efficiency in the United States depends critically on what other factors are held constant (Berger, Hunter, and Timme, 1993; Boyd and Runkle, 1993; Clark, 1988; Berger and Mester, 1997; Radecki et al., 1997; Vives, 2001; Hughes et al., 1999; and Berger et al., 2000). We contribute to this work by extending the analysis to a large number of countries and controlling for cross-country differences in institutional development and regulatory policies. ${ }^{5}$

The paper is organized as follows. Section 2 discusses the econometric methodology. Section 3 discusses the data. Section 4 presents the results, and Section 5 concludes.

\section{Methodology}

To assess the impact of bank regulations, banking sector concentration, and institutional development on bank efficiency while controlling bank-specific characteristics and the macroeconomic and financial environment, we estimate regressions of the following form:

$$
\text { Net Interest } \operatorname{Margin}_{\mathrm{i}, \mathrm{k}}=\alpha+\beta_{1} \mathrm{C}_{\mathrm{i}}+\beta_{2} \mathrm{~B}_{\mathrm{i}, \mathrm{k}}+\beta_{3} \mathrm{R}_{\mathrm{i}}+\beta_{4} \mathrm{M}_{\mathrm{i}}+\beta_{5} \mathrm{I}_{\mathrm{i}}+\varepsilon_{\mathrm{i}, \mathrm{k}}
$$

Where $\mathrm{i}$ indexes country $\mathrm{i}$, and $\mathrm{k}$ indexes bank $\mathrm{k} ; \mathrm{C}_{\mathrm{i}}$ is a measure of bank concentration in country $i$; $B_{i, k}$ is a vector of bank-specific characteristics for bank $k$ in country $i$; $R_{i}$ is a vector of

\footnotetext{
${ }^{5}$ Existing research on economics of scope and scale also focuses on the U.S. banking industry and generally does not find large cost savings or efficiency gains from consolidation (Berger et al., 1987; Ferrier et al., 1993; Rhoades, 1993, 1998; Peristiani, 1997). Indeed, researchers find that the cost curve facing U.S. banks is very flat, with estimates of scale-efficient size as low as $\$ 100$ million of assets (Berger and Humphrey, 1991; Boyd and Runkle, 1993; Clark, 1996; Berger, Demsetz, and Strahan, 1999). We do not estimate a cost curve for banks. In examining the determinants of net margins, however, we do examine bank size while controlling for the independent effects of bank regulations, bank concentration, the macroeconomic environment, institutional development, and other bank specific traits.
} 
regulatory restrictions on banks; $\mathrm{M}_{\mathrm{i}}$ is a vector of macroeconomic and financial system control variables;

$\mathrm{I}_{\mathrm{i}}$ is a vector of institutional development indicators; and $\varepsilon_{\mathrm{i}, \mathrm{k}}$ is the residual. As stressed above, we examine overhead expenditures instead of net interest margins in robustness checks. We obtain extraordinarily consistent results using overhead expenditures and report the only discrepancy below.

Since the model includes country-specific variables, we use a generalized least squares estimator with random effects. The random effects specification is supported by the Breusch and Pagan (1980) Lagrange multiplier test which strongly rejects the null hypothesis that errors are independent within countries.

To conduct the analyses, we need measures of (1) net interest margins, (2) bank concentration, (3) bank-specific characteristics that may influence interest margins, (4) regulatory policies, (5) cross-country differences in the macroeconomic environment and the level of stock market development, and (6) cross-country differences in the level of institutional development, e.g., the degree to which broad, national institutions support private property rights and promote economic openness and competition in general.

\section{Data}

We use two main data sources. Bank-level information from 72 countries on over 1400 banks is from the BankScope database provided by Fitch-IBCA. The BankScope database has comprehensive coverage in most countries, accounting for over 90 percent of all banking assets. As specified in more detail below, we use data over the 1995-1999 period. One advantage of using data averaged over the 1995-99 period is that we smooth variables that vary over time. Information on commercial bank regulations is obtained from the Barth, Caprio and Levine 
(2001b, 2003) database. Since the regulatory data are for commercial banks, we use bank-level data on commercial banks from the BankScope database. Also, focusing on commercial banks enhances the comparability of banks in our sample since some countries have banks that are not classified as commercial banks. Details of sources and variable definitions are provided in the Appendix.

\subsection{Net Interest Margin}

Net interest margin equals interest income minus interest expense divided by interestbearing assets and is average over 1995-1999. The net interest margins measures the gap between what the bank pays the providers of funds and what the bank gets from firms and other users of bank credit. Since the net interest margin focuses on the conventional borrowing and lending operations of the bank, we normalize by interest-bearing assets rather than total bank assets. Table 1 shows that Belarus, Burundi, Ghana, and Moldova are notable for their margins of over 10 percent, whereas countries like Switzerland and Netherlands have very low margins of less than two percent.

We use a variety of control variables and sensitivity checks to mitigate problems with interpreting the net interest margin variable. We want to hold a sufficient amount constant such that we can interpret greater net interest values as reflecting either operational inefficiency or market power. Confounding issues arise, however. For instance, banks engaging in fee income generating activities may have different net interest margins because of cross-subsidization of activities. For example, commercial banks may reduce lending rates to borrowers that also use bank services that generate fee and commission income, such as underwriting of securities and consulting advice on mergers and acquisitions. In this case, cross-bank differences in net interest margins may reflect difference in bank activity, rather than differences in efficiency or 
competition. Also, bank inefficiencies and market conditions may yield high overhead costs rather than large interest margins. Thus, cross-bank differences in net margins may reflect choices regarding whether to enjoy high overhead costs or large margins rather than reflecting differences in efficiency and competition. Furthermore, bank margins may reflect different asset allocations and risk tastes of firms. These measurement and interpretational issues emphasize the need to control for bank specific characteristics, conduct an array of sensitivity checks, and to use alternative measures of bank efficiency/performance. ${ }^{6}$ As discussed above, we confirm the results using overhead expenditures as an alternative dependent variable, which we define below.

\subsection{Concentration}

Bank concentration equals the fraction of bank assets held by the three largest commercial banks in the country and is averaged over 1995-99. Bank concentration is computed using bank-level data from the BankScope database. Table 1 shows that concentration is quite different across countries. It ranges from a low of 20 percent for the U.S. to 100 percent in Burundi and Rwanda. But high concentration is not only a developing country phenomenon. Belgium, Denmark, the Netherlands and Switzerland have concentration levels over 70 percent. For robustness, we confirm this paper's results using alternative bank concentration measures that we discuss below.

\subsection{Bank-specific Control Variables}

We control for bank-specific traits. We use 1995 values to reduce potential simultaneity with interest margins, which is computed over the period 1995-1999. The results, however, do

\footnotetext{
${ }^{6}$ Studies in the United States focusing on the efficiency-structure relationship have used price data from extensive surveys conducted by the Federal Reserve System. See for example Berger and Hannan (1989). In these studies, banks are assumed to be more efficient if they set prices that are more favorable to customers (higher deposit rates, lower loan rates); in other words if they have lower ex-ante margins. Such data are not available on a cross-country basis.
} 
not change when using bank-specific control variables averaged over the 1995-99. Moreover, we obtain the same results on the country-specific variables when we omit the bank-specific variables altogether. Thus, endogeneity problems from the bank-specific variables are not biasing the conclusions on our variables of focus: bank regulations, bank concentration, and institutional development.

Bank size equals the logarithm of total bank assets in millions of US dollars. Size may be an important determinant of net interest margins if there are increasing returns to scale in banking. As emphasized in the Introduction, however, we do not estimate cost functions for each of the banks in our sample, so we do not explore the issue of increasing returns in detail. Rather, we focus on the regulatory, concentration, and institutional determinants of net interest margins while controlling for bank size. Table 1 indicates considerable cross-country variability in the average size of banks.

Bank equity equals the book value of equity divided by total assets. Some theories suggest that well-capitalized banks face lower expected bankruptcy costs and hence lower funding costs. According to this view, higher bank equity ratios imply larger net interest margins when loan rates do not vary much with bank equity. ${ }^{7}$

Fee income equals non-interest-operating income divided by total assets. Banks have different product mixes. These differences may influence the pricing of loan products. Some, for instance, argue that well-developed fee income sources will produce lower interest margins

\footnotetext{
${ }^{7}$ Table 1 suggests that there is quite a bit of variation in bank capitalization despite international capital adequacy requirements. Banks in Japan, Finland, Rwanda, and Korea have very low capital ratios of less than five percent. Banks in Mexico appear to be very highly capitalized with ratios of over 20 percent. Such a wide variance in figures raises the question whether the data are comparable across countries. BankScope organizes the accounting data so as to be comparable internationally. However, differences in accounting conventions regarding the valuation of assets, loan loss provisioning, hidden reserves and other problems remain. For example, although efforts were made to use a consistent definition of equity, the observed variation may still to a certain extent reflect differences in what is considered capital in different countries. Thus, we conducted the analyses both with and without bank equity in the regressions and found very similar results to those reported below.
} 
due to cross-subsidization of bank activities. Thus, we control for fee income in assessing the impact of bank regulations, bank concentration, and national institutions on bank margins.

Liquidity equals the liquid assets of the bank divided by total assets. We use this indicator to control for differences in bank assets. Banks with high levels of liquid assets in cash and government securities may receive lower interest income than banks with less liquid assets. If the market for deposits is reasonably competitive, then greater liquidity will tend to be negatively associated with interest margins.

Bank risk equals the standard deviation of the rate of return on bank assets over the period 1995-99. Some hold that banks operating in more risky environment will tend toward an equilibrium characterized by a high net interest margin to compensate for this risk. Thus, to assess the independent effect of regulations, bank concentration, and institutions on bank margins, we present regressions controlling for individual bank risk.

Overhead equals overhead costs divided by total assets. We use this to capture cross-bank differences in the organization and operation of the bank. Different organizations will choose different business systems, product mixes, and asset allocations with consequently different overhead cost structures. Also, cost inefficiencies or low levels of market competition may be reflected in high overhead costs. Given that overhead may measure cost inefficiency and market competition, we first conduct the analyses excluding overhead as a regressor. Then, we use overhead as an alternative measure of bank efficiency/performance, i.e., as the dependent variable (using overhead averaged over the 1995-1999 period). Finally, we include overhead (in 1995) as a control variable. These different analyses confirm the paper's conclusions.

Market share equals the bank's assets divided by total commercial bank assets in the economy. A bank that dominates the national market may enjoy a larger net interest income than 
a bank that does not control much of the market even after controlling for bank size. In other words, a bank with a large market share may exert market power to enjoy a higher net interest margin. Note this is different from concentration. Concentration is not computed at the banklevel; it is a national characteristic. Clearly, there is a relationship. In the case of a country with a single bank, market share and concentration will both equal one. Just as clearly, however, there can be concentrated banking systems in which many banks do not have much market share. Indeed, although the Market share and Bank concentration variables are significantly correlated, the correlation coefficient is quite low (0.12). We conduct the bulk of the analysis without market share and then show that the results are robust to its inclusion.

\subsection{Regulatory Variables}

Fraction of entry denied equals the fraction of entry applications denied. From Table 2 we see that this figure is particularly high for countries such as Bangladesh, Egypt, Ghana, Kenya, and Thailand. On the other extreme, many countries including Germany, Switzerland and the United States have granted licenses to all applicants. One problem with this measure is that in the absence of applications - which may itself indicate the presence of insurmountable entry barriers - this variable is not defined. However, when we replace the missing values with ones in those countries that received zero entry application, we obtain very similar results to those reported below. Also, we found similar results when we separately examine the fraction of entry denied for domestic and foreign applicants respectively. ${ }^{8}$

\footnotetext{
${ }^{8}$ We also examined Foreign ownership, which equals the proportion of banking assets held in foreign-controlled banks - defined as 50 percent or more foreign-owned. Table 2 shows that there is a wide variation in foreign ownership in the sample. In Ghana, Hungary, and Jordan, foreign owned banks represent greater than 50 percent of the banking system. At the other extreme, India, Rep. of Korea, and Nigeria have negligible foreign ownership. While we find a close relationship between net interest margins and restrictions on bank entry, we do not find that foreign ownership per se is important for accounting for interest margins. See, Levine (2003) for more on the impact of foreign banks.
} 
Activity restrictions is an indicator of the degree to which banks face regulatory restrictions on their activities in securities markets, insurance, real-estate, and owning shares in non-financial firms. Activity restrictions may also have an important impact on bank efficiency by reducing competition and limiting economies of scope (Barth, Caprio and Levine, 2001a;b; 2003). The indicator potentially ranges from 0 to 4 , where higher values indicate greater restrictions. Indonesia and Japan have severe restrictions on bank activity, with values of 3.75 and 3.5 respectively. Germany, Austria, the United Kingdom, and Switzerland do not impose many restrictions on bank activities (Activity restrictions equals 1.25). In our sample, banks differ substantially in their ability to engage in different activities as noted in Tables 2 and 3.

Reserve requirements takes on the value one if there are reserve or liquidity requirements and zero otherwise. Table 2 shows that about a quarter of the countries in the sample have no reserve requirements. To the extent that reserve holdings are not remunerated or remunerated at less-than-market rates, these regulations impose a tax on the bank. Thus, we assess whether reserve requirements influence bank net interest margins. ${ }^{9}$

Banking freedom is an overall indicator of banking freedom that ranges from 1 to 5 . Larger values signify more freedom. This variable comes from the Economic Freedom Index of the Heritage Foundation and is designed to provide an overall measure of the openness of the banking industry and the extent to which banks are free to operate their businesses. Since it may be difficult to identify a single, key regulation that explains net interest margins, we also examine this overall index of bank freedom.

\subsection{Macroeconomic and Financial System Control Variables}

Table 2 reports the economic and financial system control variables. 
Inflation equals the annual rate of the change in CPI index. Boyd, Levine and Smith (2001) show that countries with high inflation have underdeveloped financial systems and banks. Huybens and Smith (1999) develop a theoretical model in which interest margins tend to rise in the presence of inflation. Thus, we control for inflation in our analyses.

GDP growth equals the rate of real per capita GDP growth. If investment opportunities in an economy are correlated with the business cycle, there may exist a positive relationship between business opportunities for banks and the growth rate of the economy.

Total value traded equals the trading of domestic equities on domestic exchanges as a share of GDP. We include this measure of stock market development (Levine and Zervos, 1998) because countries with better functioning markets may create a competitive environment that puts downward pressure on bank interest margins.

State ownership equals the share of banking system assets that are in state-owned banks, where state-owned is defined as 50 percent or more state-ownership. This measures government involvement in the banking industry. Banking systems dominated by state-banks tend to be inefficient and less open to entry. La Porta, Lopez-de-Silanes, and Shleifer (2002) find that the extent of state ownership of a country's banking system is an indicator of the banking system's efficiency in financing the private sector. Banking systems dominated by state-banks are also more likely to face restrictions on their activities. In our sample, Bangladesh, Belarus, Burundi, Egypt, India, Romania and Russia have banking systems where state-owned banks account for more than 60 percent of the market.

\footnotetext{
${ }^{9}$ We also examine the stringency of capital requirements as computed by Barth, Caprio, and Levine (2003). The capital stringency index, however, did not robustly enter the net interest margins regression significantly.
} 


\subsection{Institutional Impediments to Competition}

Besides examining specific regulatory restrictions on competition and the impact of bank concentration on net interest margins, we also consider three indexes of the overall institutional

environment. In particular, we assess whether bank regulation and concentration influences bank interest margins beyond the overall institutional structure of the economy.

Property rights is an indicator of the protection of private property rights. It ranges from 1 to 5 . Higher values signify greater protection of private property rights. There are some countries that do a poor job of protecting private property rights. Rwanda's Property Rights index equals one, while it equals two for Bangladesh, Burundi and Romania. While a large number of countries have Property Rights index values of five.

KKZ Institution index is an aggregate index of the level of institutional development. Kaufman, Kraay, and Zoido-Loboton (2001) compile information on (i) voice and accountability, i.e., the extent to which citizens can choose their government and enjoy political rights, civil liberties, and an independent press, (ii) political stability, i.e., a low likelihood that the government will be overthrown by unconstitutional or violent means, (iii) government effectiveness, i.e., the quality of public service delivery, competence of civil servants, and the absence of politicization of the civil service, (iv) light regulatory burden, i.e., relative absence of government controls on goods markets, government interference in the banking system, excessive bureaucratic controls on starting new businesses, or excessive regulation of private business and international trade, (v) rule of law, i.e., protection of persons and property against violence or theft, independent and effective judges, contract enforcement, (vi) freedom from graft - absence of the use of public power for private gain, corruption. 
Economic freedom equals an overall index of economic freedom. It measures the extent to which individuals and firms feel free to conduct their businesses. Since Economic freedom and the KKZ Institution index explicitly include information on the freedom to conduct banking operations, we do not include the indexes and the bank regulation variables simultaneously in the analyses. Including Economic freedom and the KKZ Institution index simultaneously with the regulatory variables, however, confirms the results below. Economic freedom ranges in value from 1 to 5, with greater values signifying better protection of freedoms. The United Kingdom, the United States, and Switzerland have indexes of greater than 4.05. Burundi and Rwanda have Economic Freedom indexes of less than 1.9.

GDP per capita equals real per capita GDP expressed in thousands of 1995 US dollars. Since it is very difficult to define and measure the important features of well-functioning institutions, we also use GDP per capita as a general indicator of institutional development. Table 2 provides data on GDP per capita.

A broad set of research suggests that better institutions will promote greater competition throughout the economy. This work predicts that better institutions will negatively influence net interest margins (Engerman and Sokoloff, 1997; Acemoglu, et al., 2001; Easterly and Levine, 2003). However, Bianco, Jappelli, and Pagano's (2001) research indicates that the impact of overall institutional quality on net interest margins is theoretically ambiguous. On the one hand, improvements in the institutional environment (encompassing better property rights, stronger contract enforcement, and a higher level judicial efficiency) increase the value of collateral for bank loans and therefore reduce the cost of financial intermediation for existing borrowers. On the other hand, such improvements can extend the credit market to low-grade borrowers and thereby raise the average interest rate paid on loans. As a result, the impact of better institutions 
on net interest margins could be ambiguous. We empirically examine the impact of overall institutional development on net interest margins.

\subsection{Summary Statistics}

The Table 3 correlations highlight key relationships. The results indicate that tighter regulatory restrictions (more Fraction entry denied, more Activity restrictions, less Banking freedom) and higher levels of bank concentration are associated with bigger net interest margins. Furthermore, the correlations show that better institutions (Property rights protection, KKZ Institution index, Economic freedom) are negatively correlated with bank interest margins and negatively associated with regulatory restrictions. Furthermore, macroeconomic instability, as proxied by inflation, is positively associated with net interest margins, while greater stock market development (Value traded) is negatively linked with bank interest margins. The correlations among these national characteristics suggest that it is important to control for a range of factors in assessing the impact of any of these country traits on the cost of financial intermediation.

Moving beyond correlations, we now examine the relationship between net interest margins and bank regulations, bank concentration, and the institutional environment while controlling for bank-specific characteristics and the macroeconomic and financial environment.

\section{The Results}

\subsection{Bank-specific Effects and Concentration}

Table 4 presents regressions of net interest margin on bank specific variables, bank concentration, and the regulatory variables. Depending on data availability for the regulatory variables, there are between 55 and 71 countries and between 1217 and 1372 banks. The table provides within-country and between-country $\mathrm{R}^{2 \text { s, }}$ for each regression. 
First, consider the bank-specific variables in Table 4. Large banks tend to have lower net interest margins than small banks. This is consistent with models that emphasize the positive role of size arising from scale efficiency. Banks that hold a high fraction of liquid assets have lower net interest margins. This is consistent with banks receiving lower returns on holding cash or securities, but facing a competitive market for deposits. Highly capitalized banks have higher margins, which is consistent with theories stressing that highly capitalized banks can charge more for loans and/or pay less on deposits because they face lower bankruptcy risks. Finally, banks engaging in fee-based activities tend to have lower margins, consistent with - though not direct evidence of - cross-subsidization of bank activities.

Now, consider concentration. As shown in Table 4, bank concentration enters positively and significantly at the five-percent level in all of the regressions. While the impact of concentration on net interest margins is not inconsequential, the economic magnitude is not huge. For instance if Romania were to change from its very highly concentrated banking structure (Bank concentration $=0.78)$ to the level in Poland $(0.57)$, this would represent a onestandard deviation change in bank concentration. If we use the coefficient from regression 2 (2.3), Romania's reduction in bank concentration would translate into a reduction in its net interest margin from 8.45 to 7.97 , which is a bit less than one-fourth of a standard deviation drop in the net interest margin. The economic effect of concentration is further illustrated by comparing Burundi and Kenya. Burundi's level of bank concentration is 1, i.e., the three largest commercial banks fully account for the banking system in Burundi. If it had the level of bank concentration in Kenya (0.57), this would involve a two-standard deviation reduction in bank concentration. Again using the coefficient from regression 2, Burundi's two-standard deviation reduction in bank concentration would translate into a reduction in its net interest margin from 
10.74 to 9.95 , which is about 0.40 of a standard deviation, and would not dramatically close the gap with Kenya's net interest margin (7.46).

\subsection{Regulatory Restrictions}

Table 4 also evaluates the impact of regulatory variables on net interest margins. We include (1) Fraction of entry denied, (2) Activity restrictions, (3) Reserve requirements, and (4) Banking freedom one-at-a-time while controlling for Bank concentration and the bank-specific factors.

The Table 4 results clearly indicate that regulatory restrictions substantively increase net interest margins. First, in countries that deny a higher fraction of bank entry applications, margins are larger. This is consistent with the view that restricting entry protects existing banks and allows them to enjoy large interest margins. Note this is the only finding that differs when using overhead expenditures instead of net interest margins as the dependent variable. With overhead expenditures as the dependent variable, the restricting entry index does not enter significantly at the 0.05 level.

The Table 4 regressions also indicate that, in countries that restrict banks from engaging in non-traditional activities, such as securities underwriting, real estate, owning non-financial firms, and insurance, margins tend to be larger. The economic size of the effect is substantial. For instance, if Mexico had the same level of restrictions on activities as Korea (2.25 instead of 3), this one-standard deviation drop in Activity restrictions would induce a full percentage point drop in net interest margins in Mexico according to regression 2 in Table $4\left(0.75^{*} 1.4\right)$. Thus, a one-standard deviation drop in Activity restrictions translates into 0.6 of a standard deviation drop in the net interest margin. Third, consistent with some theories, reserve requirements tend to boost net interest margins. This relationship is not very strong, however; the coefficient is 
significant at the 0.10 level. Finally, greater regulatory restrictions on operating a banking business in general are associated with higher banking margins. In sum, regulatory restrictions tend to boost interest margins.

\subsection{The Macroeconomic and Financial Sector Environment}

Tables 5 and 6 examine the relationship between net interest margin, bank concentration, bank-specific traits, and selected features of the macroeconomic and financial sector environment. We do this both to study the relationship between net interest margins and these macroeconomic and financial sector controls and to assess the robustness of the findings on bank concentration and the bank-specific features to controlling for national characteristics. Table 5 reports results without the regulatory variables. Table 6 adds the regulatory variables.

The macroeconomic and financial features help explain cross-bank net interest margins (Table 5). First, higher inflation rates are positively associated with net interest margins. According to the estimates, a one-standard deviation increase in the rate of inflation (i.e., an increase in the inflation rate of nine percentage points) induces a boost in the net interest margin of 0.36 of a percentage point $\left(9^{*} 0.04\right)$. Thus, while significant, inflation's impact on net interest margins is not economically huge. Second, the regression results indicate that economic growth is negatively associated with net interest margins using a 10 percent significance level, so that economic growth is weakly associated with a drop in margins. Third, we also examine whether other segments of the financial sector influence bank margins. Total value traded enters negatively and significantly in regression (3) of Table 5. The coefficient estimate suggests that a one standard deviation increase in total value traded will reduce net interest margins by almost a full percentage point $\left(2.8^{*} 0.35\right)$, which is about one-half of a standard deviation drop in net interest margins. More concretely, the estimates suggest that if Mexico had the same level of 
stock market development as the United States (0.70 instead of 0.12), then this would eliminate the difference in the net interest rate margin between the United States (4.3) and Mexico (5.7). Fourth, we also observe that the degree of state ownership of the banking industry is positively linked with net interest margins.

In Table 5, we also include all the macroeconomic and financial sector indicators simultaneously with bank concentration and bank-specific controls. The data indicate that inflation retains a strong, positive independent relationship with net interest margins while controlling for the other macroeconomic variables. The other macroeconomic and financial controls, however, are no longer significantly correlated with net interest margins at the five percent significance level. The broad measures of macroeconomic and financial conditions are highly correlated with each other (Table 3). Finally, note that the Table 5 results on the bank specific variables and Bank concentration are very similar to the Table 4 results when we control for the regulatory environment.

\subsection{Regulatory Environment, plus Controlling for Inflation}

Next we examine the impact of bank regulations and bank concentration on net interest margins while controlling for bank characteristics and inflation (Table 6). We report the results while controlling for only the inflation rate and not the other macroeconomic and financial sector features because (i) theory suggests that inflation influences interest margins, (ii) inflation remained significantly associated with the net interest margin when including additional macroeconomic and financial controls in Table 5, (iii) the macroeconomic/financial variables are highly correlated (Table 3), and (iv) we obtain the same results when using the other macroeconomic/financial controls. Finally, note that inflation is positive and significant across the different specifications in Table 6. 
The Table 6 results confirm that restrictive bank regulations boost net interest margins when controlling for macroeconomic conditions. When controlling for inflation, Fraction of entry denied and Activity remain significantly positively correlated with net interest margin. Banking freedom enters with a significantly negative coefficient.

Furthermore, note that the relationship between net interest margins and bank concentration virtually vanishes when including inflation and the regulatory environment. When controlling for either Activity restrictions, Reserve requirements, or Banking freedom, concentration enters significantly only at the 10 percent level and concentration enters insignificantly when controlling for the Fraction of entry denied. Also, note that concentration never enters negatively and significantly. Thus, the results do not provide supportive evidence for theories stressing that a few, highly efficient banks will dominate the market, leading to a negative associate between concentration and efficiency when controlling for impediments to competition. These results do not reject that the hypothesis that there are economic forces at play that induce more efficient banks to capture greater market share. Rather, this paper's more limited conclusion is that after we control for macroeconomic stability and include proxy measures - albeit imperfect measures-- of regulatory impediments to competition, concentration is unrelated to bank net interest margins at the 0.05 significance level.

\subsection{Institutional Setting}

In Table 7 we examine the impact of the institutional setting on bank net interest margins when controlling for Bank concentration, inflation, and bank-specific controls. Then, in Table 8, we expand the analysis by also including regulatory restrictions.

First, the results document a strong link between institutions - such as Economic freedom, Property rights protection, and the KKZ Institution index - and net interest margins 
(Tables 7 and 8). Countries where the overall institutional environment is conducive to private sector competition tend to have lower interest margins. The results suggest that a one-standard deviation improvement in Economic freedom (0.54) would lower net interest margins by 1.1 percentage point, which more than one-half of a standard deviation. Put differently, the coefficient estimates in Table 7 (regression 3) imply that if Mexico had the same level of Economic freedom as the United States (4.2 instead of 2.9), this would more than eliminate the net interest difference of the two countries by bringing Mexico's net interest margin of 5.7 down below the U.S. level of 4.3. Thus, the overall institutional environment is importantly linked with net interest margins.

Second, after controlling for the institutional environment, Bank concentration no longer enters significantly even at the 0.10 significance level (Tables $6,7,8$ ). While concentration remained significantly associated with net interest margins at the 0.10 when controlling for regulatory restrictions (Table 6), Tables 7 and 8 show that concentration enters insignificantly when controlling for overall institutional development.

Third, when we include concentration, bank-specific controls, inflation, regulatory restrictions, and Property rights simultaneously, we find that (1) Property rights matter for explaining net interest margins, (2) regulatory restrictions do not provide additional explanatory power, (3) inflation remains significantly positively associated with net interest margins, and (6) the remaining bank-specific controls remain significant as discussed above. As noted, we do not include the other institutional indicators in Table 8 because the KKZ Institution index and Economic freedom measure include information on bank regulations. This would bias the results against finding a significant coefficient on the regulatory restriction measures. Indeed, we get the same results when including the KKZ Institution index and Economic freedom measure. 
Since the regulatory variables do not enter significantly when including the Property rights index, this suggests that bank regulations reflect something broader about the competitive environment.

We interpret these results as suggesting that there are broad national approaches to competition and property rights that help explain economic efficiency throughout the economy, including the banking industry. Once we account for these broad institutions, bank specific regulations and bank competition have no additional explanatory power.

\subsection{Robustness}

We have conducted a large number of sensitivity analyses. Many of these have already been mentioned. Here we mention some additional checks.

First, we confirm the results using three alternative measures of bank concentration (Table 9). The three measures are as follows. Bank concentration (Top-5) equals the fraction of commercial bank assets held by the five largest commercial banks in the country. This measure differs from our basic measure of bank concentration by taking the share of the five rather than three largest banks. Bank concentration (All) equals the fraction of bank assets held by the three largest banks in the country. This measure differs form our basic measure of bank concentration by using data on not only commercial banks, but also on savings banks, cooperative banks, and non-bank credit institutions to calculate the concentration ratio. Finally, Bank concentration (Deposits) equals the share in total deposits of the deposits of the five largest banks in the country. Unlike the other three concentration measures, this measure is not constructed using Bankscope data, but is taken from Barth, Caprio, and Levine (2001b, 2003). This indicator is based on bank deposits rather than assets, and is constructed from a survey of bank regulatory and supervisory authorities in the respective countries. While the survey measure does not suffer 
from problems of coverage associated with the three BankScope measures, it is sensitive to different definitions used across the different countries and might therefore be subject to measurement error. The survey was undertaken in 1999. The Bankscope measures of concentration are calculated as averages over the period 1995 to 1999.

The correlation coefficients between the different concentration measures are high and significant at the one percent level (the correlation at the country level with Bank concentration is 0.97 for Bank concentration (Top-5), 0.97 for the Bank concentration (All), and 0.85 for the Bank concentration (Deposits)). Tables 1 and 3 also provide summary statistics on these alternative measures. Table 9 indicates the consistency of the results using these different concentration measures.

Second, we focused on countries with very high concentration levels. Specifically, we created dummy variables for those countries with concentration values of greater than 80 percent. We then examined whether countries with these very high concentration levels were different, i.e., did very high concentration imply high net interest margins even when controlling for the institutional environment. Again, we find that once we account for broad national institutions, bank concentration and a dummy variable that identifies highly concentrated systems have no additional explanatory power (Table 10).

Third, as emphasized in the Introduction, we confirm the results using overhead expenditures as a share of bank assets as the dependent variable. The Table 11 findings confirm this paper's conclusions. Bank concentration and regulatory restrictions do not help explain cross-bank differences in overhead costs when controlling for the overall level of institutional development. 
Fourth, we control for the riskiness and profitability of individual banks. Since banks that assume different levels of risk may charge different interest rates, we control for the standard deviation of the return on assets of each bank. As show in Table 12, this does not alter our findings. We further extended the analyses in Table 12 by controlling for bank profits as measured by return on assets. Again, controlling for bank risk and return on assets did not change the results.

Fifth, Table 13 presents pure cross-country comparisons by averaging across the banks in each country. Thus, we use one observation per country and do not control for any bank-specific factors. The dependent variable is the average net interest margin across the banks in a particular country. These regressions eliminate the bank-specific information. Thus, if bank-specific endogeneity is driving the early results, then removing bank specific-effects should reverse the findings. That is not the case. As show, bank concentration is unconditionally positively associated with net interest margins. Furthermore, activity restrictions and banking freedom are very closely linked with net interest margins even when controlling for inflation and bank concentration. Moreover, bank concentration and regulatory restrictions become insignificant when we control for Property rights. Thus, the pure cross-country results confirm this paper's bank-level analyses.

Sixth, we also examine market share (Table 14). Unlike concentration, market share is a bank specific variable that measures the relative size of the individual bank. We again confirm the paper's findings. When controlling for market share, we find that regulatory restrictions on bank activity tends to boost net interest margins when also conditioning on bank concentration and other bank-specific factors. 
We find that market share enters positively and significantly, consistent with the view that banks that are relatively large compared to the market can exert market power to increase rents. Furthermore, when adding institutional development to the analysis, we again find that Property rights lowers net interest margins and the regulatory variables no longer enter significantly. Throughout the analysis, market share enters positively and significantly. When individual banks enjoy market power, they charge higher net interest margins even after controlling for other bank specific traits, overall market concentration, regulatory restrictions on banks, and overall level of institutional development.

Seventh, we confirm that the results hold when using bank-specific factors averaged over the 1995-99 period rather than using the initial values of the bank-specific variables (not reported).

Finally, we confirm this paper's results using alternative samples. We have re-done the analyses, for instance, omitting Latin American countries, Sub-Saharan African economies, or the United States. We obtain the same results. Furthermore, we confirm this paper's results when excluding very small countries (e.g., countries with populations of less than one million people). Similarly, for some countries, especially those with highly concentrated banking systems, we only have data on three or fewer banks. The results are unchanged when restricting the sample to countries for which we have data on four or more banks (not reported).

\section{Conclusions}

This paper investigates the impact of bank regulations, concentration, and institutions on bank net interest margins and overhead expenditures using bank level data across 72 countries while controlling for a wide array of macroeconomic, financial, and bank specific-traits. In summary, we emphasize four findings. 
First, individual bank characteristics explain a substantial part of the within-country variation in financial intermediary costs. High net interest margins and large overhead expenditures tend to be associated with small banks, banks that hold a low fraction of liquid assets, banks that hold a relatively low amount of capital, banks without substantial income from fee-based activities, and banks with a large market share. The latter finding is consistent with the view that banks that are relatively large compared to the market can exert market power to increase rents.

Second, bank regulations help explain the cost of financial intermediation. Tighter regulations on bank entry, restrictions on bank activities, and regulations that inhibit the freedom of bankers to conduct their business boost bank net interest margins. These results hold when controlling for banking sector concentration, bank-specific characteristics, and the rate of inflation. Furthermore, complimentary research does not find countervailing benefits from regulatory restrictions on bank entry, activities, or freedom in terms of (a) bank stability, (b) firms' access to external finance, (c) bank valuations, or (d) overall financial development (Beck, Demirguc-Kunt, and Levine, 2003a,b; Barth, Caprio, and Levine, 2003; Caprio, Laeven, and Levine, 2003).

Third, there is an important caveat to the finding that bank regulations explain net interest margins and overhead expenditures: bank regulations cannot be viewed in isolation from the overall institutional framework. Bank regulations reflect broader, national institutions associated with the protection of private property rights and the freedom to compete in the economy. Thus, when controlling for these broader, national institutions, bank regulations do not provide additional explanatory power of cross-bank net interest margins. Institutional development, however, does explain cross-bank differences in net interest margins. We do not interpret these 
results as suggesting that bank regulations are unimportant for explaining bank margins. Rather, we interpret the findings as consistent with a strand of literature that emphasizes that policies and regulations stem from national institutions.

Four, the evidence on the relationship between concentration and net interest margins is mixed, which is perhaps unsurprising given the conflicting predictions from theory. When controlling for bank-specific factors, concentration is positively and significantly linked with bank net interest margins. This relationship breaks down, however, when controlling for regulatory restrictions on banks and macroeconomic stability. Given the availability of data on the macroeconomic environment and regulatory impediments on banks, these results shed skeptical light on using national bank concentration measures to proxy for the competitive environment facing the banking industry. Furthermore, even when controlling for regulatory restrictions and the overall institutional environment, we never find a significant positive link between concentration and efficiency as predicted by some theories of banking. 


\section{References}

Acemoglu, Daron, Simon Johnson, and James A. Robinson. (2001). "The colonial origins of comparative development: An empirical investigation.” American Economic Review 91, $1369-1401$.

Bank for International Settlements. (2001). "The Banking Industry in the Emerging Market Economies: Competition, Consolidation, and Systemic Stability.” BIS Papers 4, Basle.

Barth, James, Gerard Caprio, and Ross Levine. (2001a). "Banking Systems Around the Globe: Do Regulation and Ownership Affect Performance and Stability?” In Financial Supervision and Regulation: What Works and What Doesn't, edited by Frederic S. Mishkin, pp. 31-88. Chicago, IL: Chicago University Press.

Barth, James, Gerard Caprio, and Ross Levine. (2001b). "The Regulation and Supervision of Banks Around the World: A new Database.” In Integrating Emerging Market Countries into the Global Financial System, Brookings-Wharton Papers on Financial Services, edited by Robert E. Litan and R. Herring, pp. 183-241. Washington, DC: Brookings Institution Press.

Barth, James, Gerard Caprio, and Ross Levine. (2003). "Bank Regulation and Supervision: What Works Best?" Journal of Financial Intermediation, forthcoming.

Beck, Thorsten, Asli Demirgüç-Kunt, and Ross Levine. (2000). “A New Database on Financial Development and Structure.” World Bank Economic Review, September, 597-605.

Beck, Thorsten, Asli Demirgüç-Kunt, and Ross Levine. (2002). "Law, Endowments, and Finance." Journal of Financial Economics, forthcoming.

Beck, Thorsten, Asli Demirgüç-Kunt, and Ross Levine. (2003a). "Bank Supervision and Corporate Finance.” University of Minnesota (Carlson School of Management), mimeo. 
Beck, Thorsten, Asli Demirgüç-Kunt, and Ross Levine. (2003b). "Bank Concentration and Crises." University of Minnesota (Carlson School of Management), mimeo.

Beck, Thorsten, Ross Levine, and Norman Loayza. (2000). "Finance and the Sources of the Growth.” Journal of Financial Economics 58, 261-300.

Becker, Gary. (1983). “A Theory of Competition Among Pressure Groups for Political Influence.” Quarterly Journal of Economics 98, 371-400.

Berger, Allen N. (1995). "The Profit-Structure Relationship in Banking - Tests of Market Power and Efficient-Structure Hypothesis." Journal of Money, Credit and Banking 27, 404-431.

Berger, Allen N., Rebecca S. Demsetz, and Philip E. Strahan. (1999). "The Consolidation of the Financial Services Industry: Causes, Consequences, and Implications for the Future.” Journal of Banking and Finance 23, 135-194.

Berger, Allen N., Robert DeYoung, Hesna Genay, and Gregory F. Udell. (2000). “Globalization of Financial Institutions: Evidence from Cross-Border Banking Performance.” Brookings-Wharton Papers on Financial Services 3, 23-125.

Berger, Allen N., and Timothy H. Hannan. (1989). “The Price-Concentration Relationship in Banking." Review of Economics and Statistics 71, 291-299.

Berger, Allen N., and Timothy H. Hannan. (1998). "The Efficiency Cost of Market Power in the Banking Industry: A Test of the 'Quiet Life' and Related Hypotheses.” Review of Economics and Statistics 80, 454-465.

Berger, Allen N., Gerald A. Hanweck, and David B. Humphrey. (1987). "Competitive Viability in Banking: Scale, Scope and Product Mix Economies.” Journal of Monetary Economics $20,501-520$. 
Berger, Allen N., and David B. Humphrey. (1991). "The Dominance of Inefficiencies Over Scale and Product Mix Economies in Banking.” Journal of Monetary Economics 28, 117-148.

Berger, Allen N., and David B. Humphrey. (1992). "Megamergers in Banking and the Use of Cost Efficiency as an Antitrust Defense." Antitrust Bulletin 37, 541-600.

Berger, Allen N., Anthony Saunders, Joseph M. Scalise, and Gregory F. Udell. (1998). “The Effects of Bank Mergers and Acquisitions on Small Business Lending." Journal of Financial Economics 50, 187-229.

Besanko, David, and Anjan V. Thakor. (1992). “Banking Deregulation: Allocational Consequences of Relaxing Entry Barriers.” The Journal of Banking and Finance 16, 909-932.

Bianco, Magda, Tullio Jappelli, and Marco Pagano. (2001). "Courts and Banks: Effects of Judicial Enforcement on Credit Markets.” CSEF Working Paper No. 58, 48 p.

Boot, Arnoud W.A., and Anjan V. Thakor. (1996). "Banking Structure and Financial Innovation.” In Universal Banking: Financial System Design Reconsidered, edited by Ingo Walter and A. Saunders, pp. 420-430. Chicago, IL: Irwin Professional Publishing.

Boyd, John H., and Stanley L. Graham. (1991). "Investigating the Banking Consolidation Trend.” Federal Reserve Bank of Minneapolis Quarterly Review, Spring, 3-15.

Boyd, John H., and Stanley L. Graham. (1998). “Consolidation in US Banking.” In Bank Mergers and Acquisitions, edited by Yakov Amihud and Geoffrey Miller, pp. 113-135. Norwell, MA: Kluwer Academic Publishers.

Boyd, John H., Ross Levine, and Bruce D. Smith. (2001). "The Impact of Inflation on Financial Sector Performance.” Journal of Monetary Economics 47, 221-248. 
Boyd, John H. and Edward C. Prescott. (1986). "Financial Intermediary-Coalitions." Journal of Economic Theory 38, 211-32.

Boyd, John H. and David E. Runkle. (1993). "Size and Performance of Banking Firms.” Journal of Monetary Economics 31, 47-67.

Breusch, Trevor S. and Adrian Rodney Pagan. (1980). "The Lagrange Multiplier Test and Its Applications to Model Specification in Econometrics." The Review of Economic Studies 47, 239-253.

Caprio, Gerard, and Daniela Klingebiel. (1999). "Episodes of Systematic and Borderline Financial Crises." World Bank, mimeo.

Caprio, Gerard, Luc Laeven, and Ross Levine. (2003). "Governance and Valuation of Banks." University of Minnesota, mimeo.

Cetorelli, Nicola, and Michele Gambera. (2001). "Banking Market Structure, Financial Dependence and Growth: International Evidence from Industry Data.” Journal of Finance $56,617-648$.

Claessens, Stijn, Asli Demirgüç-Kunt, and Harry Huizinga. (2001). “How Does Foreign Entry Affect Domestic Banking Markets?” Journal of Banking and Finance 25, 891-911. Claessens, Stijn, and Daniela Klingebiel. (2001). "Competition and Scope of Activities in Financial Services.” World Bank Research Observer 16, 18-40.

Claessens, Stijn and Luc Laeven. (2004). "What Drives Bank Competition? Some International Evidence." World Bank, mimeo.

Clark, Jeffrey A. (1996). "Economic Cost, Scale Efficiency and Competitive Viability in Banking." Journal of Money, Credit, and Banking 28, 342-64. 
Demirgüç-Kunt, Asli, and Vojislav Maksimovic. (1998). "Law, Finance, and Firm Growth." Journal of Finance 53, 2107-2137.

Demirgüç-Kunt, Asli, and Harry Huizinga. (1999). "Determinants of Commercial Bank Interest Margins and Profitability: Some International Evidence.” World Bank Economic Review $13,379-408$.

Demsetz, Rebecca S., and Philip E. Strahan. (1997). "Diversification, Size, and Risk at Bank Holding Companies." Journal of Money, Credit, and Banking 28, 300-13.

Demsetz, Harold. (1973). “Industry Structure, Market Rivalry, and Public Policy,” Journal of Law and Economics 16, 1-9.

Demsetz, Harold. (1974). “Two Systems of Belief about Monopoly.” In Industrial Concentration: The New Learning, edited by Harvey J. Goldschmid, Michael H. Mann, and J. Fred Weston, pp. 93-100. Boston: Little-Brown.

Diamond, Douglas W. (1984). "Financial Intermediation and Delegated Monitoring." Review of Economic Studies, 51, 393-414.

Easterly, William, and Ross Levine. (2003). “Tropics, Germs, and Crops: How Endowments Influence Economic Development.” Journal of Monetary Economics, forthcoming. Engerman, Stanley L., and Kenneth L. Sokoloff. (1997). "Factor Endowments, Institutions, and Differential Paths of Growth Among New World Economies: A View from Economic Historians of the United States." In How Latin America Fell Behind, edited by Stephen Haber, pp. 260-304. Stanford, CA: Stanford University Press.

Ferrier, Gary D., Shawna Grosskopf, Kathy J. Hayes, and Suthathip Yaisawarng. (1993). "Economies of Diversification in the Banking Industry: A Frontier Approach.” Journal of Monetary Economics 31, 229-249. 
Gande, Amar, Manju Puri, and Anthony Saunders. (1999). "Bank Entry, Competition, and the Market for Corporate Securities Underwriting." Journal of Financial Economics 54, 165-195.

Gerschenkron, Alexander. (1965). Economic Backwardness in Historical Perspective. New York, NY: Praeger.

Gilbert, R. Alton. (1984). "Bank Market Structure and Competition: A Survey.” Journal of Money, Credit and Banking 16, 617-645.

Goldberg, Lawrence G. and Anoop Rai. (1996). "The Structure-Performance Relationship for European Banking.” Journal of Banking and Finance 20, 745-771.

Graddy, Duane B. and Reuben Kyle. (1979). "The Simultaneity of Bank Decision-Making, Market Structure, and Bank Performance.” Journal of Finance 34, 1-18.

Group of Ten. (2001). Report on Consolidation in the Financial Sector. Bank for International Settlements: Basel, Switzerland.

Haber, Stephen H., Armando Razo, and Noel Maurer. (2003). The Politics of Property Rights: Political Instability, Credible Commitments, and Economic Growth in Mexico, Cambridge, UK: Cambridge University Press.

Hannan, Timothy H. and Allen N. Berger. (1991). "The Rigidity of Prices: Evidence from the Banking Industry.” American Economic Review 81, 938-945.

Hughes, Joseph, William Lang, Loretta Mester, and Choon-Geol Moon. (1999). “The Dollars and Sense of Bank Consolidation.” Journal of Banking and Finance 23, 291-324.

Huybens, Elisabeth, and Bruce D. Smith. (1999). "Inflation, financial markets, and long-run real activity.” Journal of Monetary Economics 43, 283-315. 
International Monetary Fund. (2001). Financial Sector Consolidation in Emerging Markets,

Chapter V. International Capital Market Report.

Jayaratne, Jith, and Philip E. Strahan. (1996). “The Finance-Growth Nexus: Evidence from Bank Branch Deregulation.” Quarterly Journal of Economics 111, 639-670.

Jayaratne, Jith, and Philip E. Strahan. (1998). "Entry Restrictions, Industry Evolution and Dynamic Efficiency: Evidence from Commercial Banking." Journal of Law and Economics 49, 239-274.

Kaufmann, Daniel, Aart Kraay, and Pablo Zoido-Lobatón (1999). “Governance Matters.” Policy Research Working Paper 2196. World Bank.

Kaufmann, Daniel, Aart Kraay, and Pablo Zoido-Lobatón. (2001). “Governance Matters II: Updated Indicators for 2000/01.” World Bank, mimeo.

Keeley, Michael C., and Gary C. Zimmerman. (1985). "Competition for Money Market Deposit Accounts." Federal Reserve Bank of San Francisco Economic Review 1, 5-27.

Kroszner, Randall S., and PhilipE. Strahan. (1999). "What Drives Deregulation? Economics and Politics of the Relaxation of Bank Branching Restrictions.” Quarterly Journal of Economics 114, 1437-67.

Lamoreaux, Naomi R. (1986). "Banks, Kinship, and Economic Development: The New England Case.” Journal of Economic History 46, 647-667.

La Porta, Rafael, Florencio Lopez-de-Silanes, Andrei Shleifer, and Robert W. Vishny. (1999). “The Quality of Government.” Journal of Law, Economics, and Organization 15, 222-279.

Levine, Ross. (2003). “Deny Foreign Bank Entry: Implications for Bank Interest Margins.” In Bank Competition, edited by Luis Antonio Ahumada and Rodrigo Fuentes. Santiago, 
Chile: Banco Central de Chile, forthcoming.

Lloyd-Williams, D. M., Phil Molyneux, and John Thornton. (1994). "Market Structure and Performance in Spanish Banking.” Journal of Banking and Finance 18, 433-443.

Macey, Jonathan R. and Geoffrey Miller. (1998). "Bank Mergers and American Bank

Competitiveness." In Bank Mergers and Acquisitions, edited by Yakov Amihud and Geoffrey Miller, pp. 175-190. Norwell, MA: Kluwer Academic Publishers.

Mayer, Colin. (1990). "Financial Systems, Corporate Finance and Economic Development.” In Asymmetric Information, Corporate Finance and Investment, edited by R. Glen Hubbard, pp. 307-332. Chicago, IL: The University of Chicago Press.

Neumark, David and Steven A. Sharpe. (1992). "Market Structure and the Nature of Price Rigidity: Evidence from the Market for Consumer Deposits." Quarterly Journal of Economics 107, 657-680.

North, Douglass. (1990). Institutions, Institutional Change, and Economic Performance. Cambridge: Cambridge University Press.

Olson, Mancur. (1993). "Dictatorship, Democracy, and Development.” American Political Science Review 87, 567-576.

Pagano, Marco. (1993). "Financial Markets and Growth. An Overview.” European Economic Review 37, 613-622.

Peltzman, Sam. (1976). “Toward a More General Theory of Regulation.” Journal of Law and Economics 18, 211-240.

Peltzman, Sam. (1977). “The Gains and Losses from Industrial Concentration.” Journal of Law and Economics 20, 229-263. 
Peristiani, Stavros. (1997). “Do Mergers Improve X-efficiency and Scale Efficiency of US Banks? Evidence from the 1980s." Journal of Money, Credit, and Banking 29, 326-337.

Petersen, Mitchell A., and Raghuram G. Rajan. (1994). "The Benefits of Lending Relationships: Evidence from Small Business Data." The Journal of Finance 49, 3-37.

Petersen, Mitchell A. and Raghuram G. Rajan. (1995). “The Effect of Credit Market Competition on Lending Relationships" Quarterly Journal of Economics 110, 407-443.

Pilloff, Steven J. (1996). "Performance Changes and Shareholder Wealth Creation Associated with Mergers of Publicly Traded Banking Institutions.” Journal of Money, Credit, and Banking 28, 294-310.

Pilloff, Steven J. and Anthony M. Santomero. (1998). "The Value Effects of Bank Mergers and Acquistions.” In Bank Mergers and Acquisitions, edited by Yakov Amihud and Goeffrey Miller, pp. 59-78. Norwell, MA: Kluwer.

Prager, Robin A. and Timothy H. Hannan. (1999). "Do Substantial Horizontal Mergers Generate Significant Price Effects? Evidence from the Banking Industry.” Journal of Industrial Economics 46, 433-452.

Radecki, Lawrence J., John Wenninger, and Daniel K. Orlow. (1997). "Industry Structure: Electronic Delivery's Potential Effects on Retail Banking.” Journal of Retail Banking Services 19, 57-63.

Rajan, Raghuram G., and Luigi Zingales. (1998). "Financial Dependence and Growth." American Economic Review 88, 559-586.

Rajan, Raghuram G., and Luigi Zingales. (2003). Saving Capitalism from the Capitalists. New York, NY: Random House. 
Rhoades, Stephen A. (1993). “The Efficiency Effects of Horizontal Bank Mergers.” Journal of Banking and Finance 17, 411-422.

Rhoades, Stephen A. (1998). “The Efficiency Effects of Bank Mergers: an Overview of Case Studies of Nine Mergers.” Journal of Banking and Finance 22, 273-291.

Shaffer, Sherrill. (1993). "A Test of Competition in Canadian Banking.” Journal of Money, Credit, and Banking 25, 49-61.

Shepherd, William G. (1982). "Economies of Scale and Monopoly Profits.” In Industrial Organization, Antitrust, and Public Policy, edited by John V. Craven, pp. 165-204, Boston: Kluwer-Nijhoff Publishing.

Simons, Katerina and Joanna Stavins. (1998). "Has Antitrust Policy in banking Become Obsolete?" Federal Reserve Bank of Boston New England Economic Review, March, $13-26$.

Smirlock, Michael. (1985). "Evidence on the (Non) Relationship between Concentration and Profitability in Banking.” Journal of Money, Credit, and Banking 17, 69-83.

Stiroh, Kevin, and Philip E. Strahan. (2003). "Competitive Dynamics of Deregulation: Evidence from U.S. Banking.” Journal of Money, Credit, and Banking, forthcoming. Vives, Xavier. (2001). "Competition in the Changing World of Banking." Oxford Review of Economic Policy 17, 535-545.

World Bank. (2000). Global Economic Prospects and the Developing Countries 2000. The World Bank.

Wurgler, Jeffrey. (2000). "Financial Markets and the Allocation of Capital.” Journal of Financial Economics 58, 187-214. 
Table 1. Bank concentration and efficiency

\begin{tabular}{|c|c|c|c|c|c|c|c|c|c|c|c|c|c|}
\hline Country name & $\begin{array}{c}\text { Net } \\
\text { interest } \\
\text { margin }\end{array}$ & $\begin{array}{c}\text { Bank } \\
\text { concentration }\end{array}$ & $\begin{array}{c}\text { Bank } \\
\text { concentration ce } \\
\text { (Top-5) }\end{array}$ & $\begin{array}{c}\text { Bank } \\
\text { oncentration c } \\
\text { (All) }\end{array}$ & $\begin{array}{c}\text { Bank } \\
\text { concentration } \\
\text { (Deposits) }\end{array}$ & $\begin{array}{c}\text { Bank } \\
\text { size }\end{array}$ & Liquidity & $\begin{array}{l}\text { Bank } \\
\text { equity }\end{array}$ & $\begin{array}{c}\text { Fee } \\
\text { income }\end{array}$ & Overhead & $\begin{array}{c}\text { Market } \\
\text { share }(\%)\end{array}$ & $\begin{array}{c}\text { Bank } \\
\text { risk }\end{array}$ & $\begin{array}{l}\text { Number } \\
\text { of banks }\end{array}$ \\
\hline Australia & 3.12 & 0.63 & 0.85 & 0.59 & 0.73 & 9.09 & 12.54 & 7.17 & 0.81 & 2.94 & 6.88 & 0.30 & 14 \\
\hline Austria & 2.16 & 0.44 & 0.58 & 0.45 & 0.38 & 6.62 & 16.09 & 7.73 & 1.55 & 2.51 & 1.15 & 0.71 & 22 \\
\hline Bahrain & 2.45 & 0.92 & 0.98 & 0.91 & 0.71 & 7.06 & 11.82 & 14.67 & 1.62 & 1.93 & 16.46 & 0.40 & 6 \\
\hline Bangladesh & 2.05 & 0.70 & 0.79 & 0.63 & 0.65 & 4.72 & 44.51 & 6.30 & 1.07 & 2.07 & 8.03 & 0.82 & 6 \\
\hline Belarus & 10.68 & 0.84 & 0.96 & 0.81 & 0.83 & 5.18 & 37.29 & 1.12 & 0.45 & 5.82 & 18.43 & 2.70 & 1 \\
\hline Belgium & 2.38 & 0.75 & 0.85 & 0.52 & 0.74 & 7.07 & 23.08 & 6.47 & 0.72 & 2.55 & 2.32 & 0.67 & 22 \\
\hline Bolivia & 5.62 & 0.61 & 0.83 & 0.46 & 0.68 & 4.50 & 19.85 & 14.90 & 0.72 & 3.85 & 8.92 & 0.94 & 11 \\
\hline Botswana & 7.03 & 0.92 & 1.00 & 0.90 & 1.00 & 5.48 & 11.46 & 10.44 & 1.44 & 4.31 & 25.00 & 0.87 & 4 \\
\hline Burundi & 10.74 & 1.00 & 1.00 & 0.96 & 0.91 & 4.16 & 20.74 & 10.12 & 1.47 & 5.20 & 50.00 & 1.25 & 2 \\
\hline Canada & 2.03 & 0.56 & 0.84 & 0.54 & 0.76 & 6.59 & 22.46 & 7.12 & 0.73 & 1.93 & 0.30 & 0.77 & 24 \\
\hline Chile & 5.02 & 0.48 & 0.71 & 0.46 & 0.59 & 6.72 & 26.16 & 12.48 & -0.53 & 3.04 & 6.91 & 0.68 & 14 \\
\hline Croatia & 5.40 & 0.62 & 0.72 & 0.58 & 0.57 & 5.12 & 24.56 & 19.64 & 2.09 & 5.48 & 4.62 & 3.02 & 21 \\
\hline Cyprus & 2.53 & 0.82 & 0.94 & 0.82 & 0.80 & 7.66 & 21.80 & 7.13 & 1.27 & 2.39 & 35.64 & 0.88 & 2 \\
\hline Czech Rep. & 2.88 & 0.72 & 0.81 & 0.61 & 0.74 & 7.11 & 13.12 & 7.84 & 1.15 & 2.41 & 7.19 & 0.94 & 13 \\
\hline Denmark & 5.28 & 0.71 & 0.80 & 0.66 & 0.79 & 5.98 & 19.58 & 10.78 & 0.41 & 3.87 & 1.91 & 0.39 & 46 \\
\hline Egypt & 2.42 & 0.58 & 0.72 & 0.57 & 0.65 & 6.90 & n.a. & 7.74 & 1.47 & 1.89 & 2.44 & 0.47 & 3 \\
\hline Estonia & 6.15 & 1.00 & 1.00 & 0.85 & 0.95 & 5.58 & 6.88 & 9.14 & 3.37 & 5.24 & 50.00 & 2.25 & 2 \\
\hline Finland & 1.99 & 0.75 & 0.94 & 0.77 & 0.97 & 9.38 & 14.14 & 5.20 & 0.73 & 1.90 & 22.69 & 0.42 & 4 \\
\hline France & 2.86 & 0.33 & 0.50 & 0.27 & 0.70 & 7.11 & 12.05 & 7.38 & 1.05 & 3.10 & 0.39 & 0.62 & 111 \\
\hline Germany & 2.66 & 0.32 & 0.42 & 0.32 & 0.12 & 6.76 & 30.25 & 9.04 & 1.21 & 2.89 & 0.33 & 0.38 & 103 \\
\hline Ghana & 11.61 & 0.79 & 0.98 & 0.75 & 0.78 & 5.52 & 49.18 & 11.59 & 5.62 & 7.68 & 30.97 & 1.05 & 2 \\
\hline Greece & 3.50 & 0.71 & 0.88 & 0.68 & 0.70 & 8.04 & 32.16 & 6.15 & 1.49 & 3.22 & 11.11 & 0.95 & 9 \\
\hline Guatemala & 7.53 & 0.26 & 0.40 & 0.26 & 0.38 & 4.50 & 23.72 & 10.33 & -0.26 & 5.84 & 3.76 & 0.60 & 14 \\
\hline Honduras & 8.82 & 0.42 & 0.64 & 0.41 & 0.52 & 4.71 & 32.68 & 9.76 & -1.47 & 5.14 & 10.09 & 0.56 & 2 \\
\hline Hungary & 4.86 & 0.53 & 0.67 & 0.51 & n.a. & 6.26 & 9.25 & 9.18 & 2.23 & 4.26 & 5.52 & 1.48 & 16 \\
\hline Iceland & 4.15 & 0.87 & 0.96 & 0.73 & n.a. & 6.95 & 9.83 & 7.16 & 2.03 & 4.07 & 32.28 & 0.39 & 3 \\
\hline India & 3.48 & 0.37 & 0.48 & 0.35 & 0.42 & 6.81 & 39.38 & 7.30 & 0.72 & 2.58 & 1.72 & 0.51 & 55 \\
\hline Indonesia & 5.62 & 0.51 & 0.67 & 0.39 & 0.53 & 5.47 & 22.47 & 11.92 & 0.37 & 2.89 & 0.46 & 2.08 & 20 \\
\hline Ireland & 3.49 & 0.68 & 0.79 & 0.62 & n.a. & 9.49 & 29.44 & 6.51 & 1.04 & 2.73 & 25.29 & 0.20 & 3 \\
\hline Israel & 3.22 & 0.76 & 0.92 & 0.76 & 0.80 & 7.53 & 12.27 & 10.36 & 1.50 & 3.16 & 8.14 & 0.31 & 12 \\
\hline Italy & 3.67 & 0.30 & 0.43 & 0.27 & 0.25 & 7.57 & 29.76 & 8.22 & 0.65 & 3.64 & 0.98 & 0.44 & 56 \\
\hline
\end{tabular}


Table 1. (cont.)

\begin{tabular}{|c|c|c|c|c|c|c|c|c|c|c|c|c|c|}
\hline Country name & $\begin{array}{l}\text { Net } \\
\text { interest } \\
\text { margin } \\
\end{array}$ & $\begin{array}{c}\text { Bank } \\
\text { concentration } \\
\end{array}$ & $\begin{array}{c}\text { Bank } \\
\text { concentration c } \\
(\text { Top-5) }\end{array}$ & $\begin{array}{c}\text { Bank } \\
\text { concentration } \\
\text { (All) }\end{array}$ & $\begin{array}{c}\text { Bank } \\
\text { concentration } \\
\text { (Deposits) }\end{array}$ & $\begin{array}{c}\text { Bank } \\
\text { size }\end{array}$ & Liquidity & $\begin{array}{c}\text { Bank } \\
\text { equity }\end{array}$ & $\begin{array}{c}\text { Fee } \\
\text { income }\end{array}$ & Overhead & $\begin{array}{c}\text { Market } \\
\text { share (\%) }\end{array}$ & $\begin{array}{c}\text { Bank } \\
\text { risk } \\
\end{array}$ & $\begin{array}{l}\text { Number } \\
\text { of banks } \\
\end{array}$ \\
\hline Jamaica & 9.43 & 0.92 & 1.00 & 0.81 & 0.74 & 5.37 & 32.91 & 9.25 & -0.35 & 7.04 & 26.69 & 1.01 & 3 \\
\hline Japan & 2.07 & 0.27 & 0.39 & 0.26 & 0.31 & 9.80 & 11.80 & 3.76 & 0.20 & 1.56 & 0.79 & 0.30 & 102 \\
\hline Jordan & 3.47 & 0.89 & 0.96 & 0.89 & 0.68 & 6.86 & 41.29 & 7.95 & 0.46 & 2.61 & 16.43 & 0.47 & 6 \\
\hline Kenya & 7.46 & 0.57 & 0.70 & 0.54 & 0.62 & 4.58 & 35.57 & 10.08 & 0.85 & 4.79 & 6.64 & 1.51 & 5 \\
\hline Korea, Rep. & 2.39 & 0.37 & 0.55 & 0.30 & 0.48 & 9.69 & 11.03 & 5.84 & 0.41 & 2.66 & 5.77 & 1.69 & 15 \\
\hline Kuwait & 1.87 & 0.68 & 0.91 & 0.67 & n.a. & 8.45 & 34.35 & 10.43 & 0.60 & 0.94 & 16.67 & 0.34 & 6 \\
\hline Latvia & 6.92 & 0.53 & 0.69 & 0.49 & n.a. & 3.44 & 11.75 & 14.14 & 3.10 & 7.03 & 6.58 & 4.55 & 10 \\
\hline Lebanon & 4.18 & 0.32 & 0.47 & 0.31 & 0.40 & 5.02 & 54.26 & 8.86 & 0.10 & 2.83 & 2.16 & 0.84 & 28 \\
\hline Lithuania & 8.43 & 0.94 & 0.98 & 0.86 & 0.90 & 5.66 & 8.48 & -0.77 & 0.54 & 6.73 & 97.80 & 1.89 & 1 \\
\hline Luxembourg & 1.19 & 0.21 & 0.32 & 0.19 & 0.27 & 6.92 & 45.02 & 5.54 & 0.61 & 1.38 & 0.77 & 0.24 & 26 \\
\hline Macedonia & 9.57 & 0.87 & 0.93 & 0.84 & 0.77 & 5.67 & 52.57 & 10.90 & 4.05 & 5.33 & 43.58 & 0.32 & 2 \\
\hline Malta & 2.28 & 0.94 & 0.99 & 0.89 & 1.00 & 6.33 & 13.37 & 6.30 & 0.36 & 1.71 & 23.48 & 0.14 & 4 \\
\hline Mauritius & 3.91 & 0.93 & 0.98 & 0.91 & 0.91 & 5.35 & 34.77 & 11.41 & 0.44 & 2.31 & 19.39 & 0.29 & 5 \\
\hline Mexico & 5.70 & 0.64 & 0.79 & 0.63 & 0.80 & 4.38 & 38.26 & 31.84 & -0.44 & 5.98 & 3.60 & 3.30 & 9 \\
\hline Moldova, Rep. & 10.03 & 0.83 & 0.98 & 0.76 & 0.71 & 2.55 & 50.69 & 11.07 & 8.88 & 6.96 & 17.54 & 2.28 & 1 \\
\hline Morocco & 5.01 & 0.77 & 0.96 & 0.61 & 0.75 & 7.82 & 28.60 & 10.36 & 0.38 & 2.09 & 16.72 & 0.10 & 2 \\
\hline Namibia & 6.64 & 0.83 & 1.00 & 0.79 & 1.00 & 5.95 & 15.08 & 5.91 & 1.22 & 4.26 & 25.00 & 0.28 & 4 \\
\hline Nepal & 5.41 & 0.77 & 0.92 & 0.77 & 0.55 & 4.39 & 37.21 & 8.08 & 1.34 & 2.45 & 25.00 & 0.55 & 4 \\
\hline Netherlands & 1.97 & 0.81 & 0.91 & 0.77 & 0.88 & 7.51 & 34.01 & 6.83 & 0.89 & 1.95 & 3.56 & 0.23 & 18 \\
\hline New Zealand & 3.03 & 0.70 & 0.95 & 0.66 & 0.91 & 8.53 & 9.08 & 6.09 & 1.10 & 2.49 & 18.92 & 0.14 & 5 \\
\hline Nigeria & 8.94 & 0.62 & 0.71 & 0.50 & 0.51 & 6.31 & 64.46 & 7.60 & 3.35 & 7.79 & 11.50 & 0.96 & 8 \\
\hline Norway & 2.68 & 0.61 & 0.70 & 0.52 & n.a. & 7.94 & 5.96 & 6.48 & 0.82 & 1.87 & 8.56 & 0.48 & 5 \\
\hline Panama & 2.86 & 0.24 & 0.35 & 0.22 & 0.30 & 5.55 & 21.93 & 9.15 & 0.93 & 1.95 & 2.36 & 0.39 & 8 \\
\hline Peru & 7.92 & 0.64 & 0.78 & 0.46 & 0.81 & 5.83 & 26.89 & 10.58 & 1.01 & 5.79 & 10.09 & 0.93 & 9 \\
\hline Philippines & 4.56 & 0.40 & 0.57 & 0.36 & 0.46 & 7.19 & 26.37 & 14.41 & 1.03 & 3.61 & 5.26 & 0.99 & 19 \\
\hline Poland & 6.81 & 0.57 & 0.69 & 0.51 & 0.57 & 5.63 & 13.08 & 14.65 & -0.24 & 3.89 & 2.95 & 0.96 & 15 \\
\hline Romania & 8.45 & 0.78 & 0.92 & 0.83 & 0.59 & 4.09 & 34.13 & 20.77 & 1.82 & 5.82 & 4.95 & 2.34 & 2 \\
\hline Russian Fed. & 5.99 & 0.43 & 0.57 & 0.38 & 0.80 & 5.54 & 53.78 & 12.94 & 5.66 & 6.61 & 7.02 & 7.80 & 4 \\
\hline Rwanda & 5.74 & 1.00 & 1.00 & 0.97 & 1.00 & 4.27 & 43.61 & 3.33 & 1.06 & 4.61 & 43.54 & 0.15 & 1 \\
\hline Singapore & 2.86 & 0.85 & 0.95 & 0.60 & n.a. & 8.78 & 13.36 & 15.23 & 0.36 & 1.18 & 18.82 & 0.47 & 5 \\
\hline Slovenia & 4.00 & 0.64 & 0.77 & 0.60 & 0.64 & 5.61 & 16.10 & 13.29 & 2.67 & 4.23 & 8.17 & 0.53 & 11 \\
\hline South Africa & 6.22 & 0.78 & 0.92 & 0.67 & 0.85 & 6.05 & 19.37 & 14.30 & 1.19 & 4.90 & 8.31 & 0.68 & 11 \\
\hline
\end{tabular}


Table 1. (cont.)

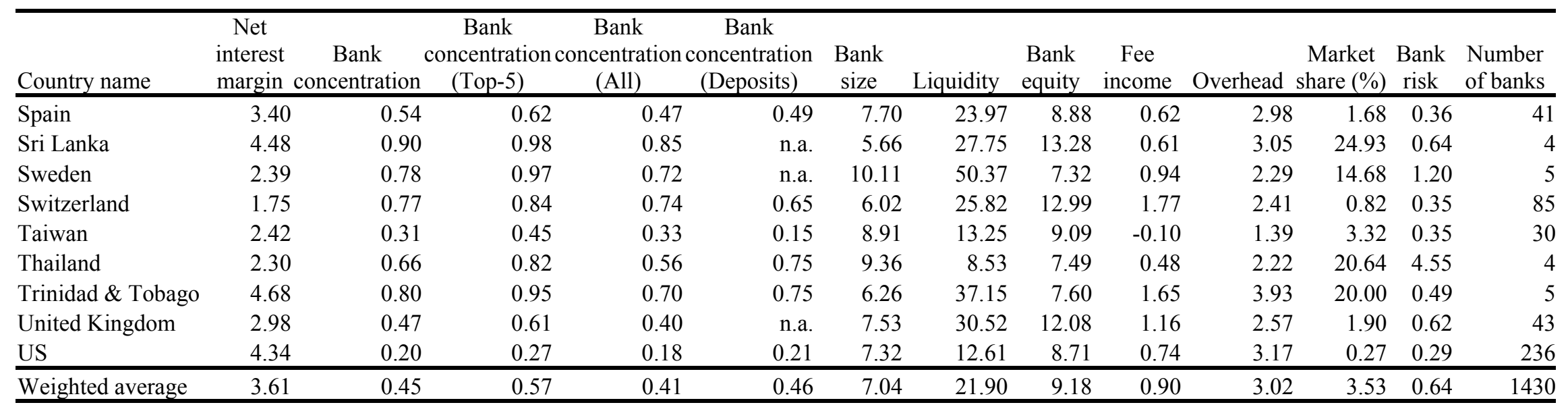

Notes: All country-level variables are averages for the period 1995-99, except Bank concentration (Deposits) for which we use data for the year 1999. All bankspecific variables are year 1995 data, except net interest margins, overhead ratios and bank risk for which we use averages for the period 1995-99. A detailed description of the definition and sources of the variables can be found in the Appendix. n.a. indicates not available. Outliers (above 95\% percentile and below $5 \%$ percentile) of the variables net interest margins through fee income are deleted from the dataset. Dataset includes commercial banks only, as defined by BankScope. Number of banks is the number of banks in the final sample for each country. The total number of countries is 72 . The total number of bank observations is 1,430.

Source: BankScope. 
Table 2. Institutional and regulatory indicators

KKZ

GDP per Value GDP Economic Property Institution Fraction Activity Reserve Banking Foreign State

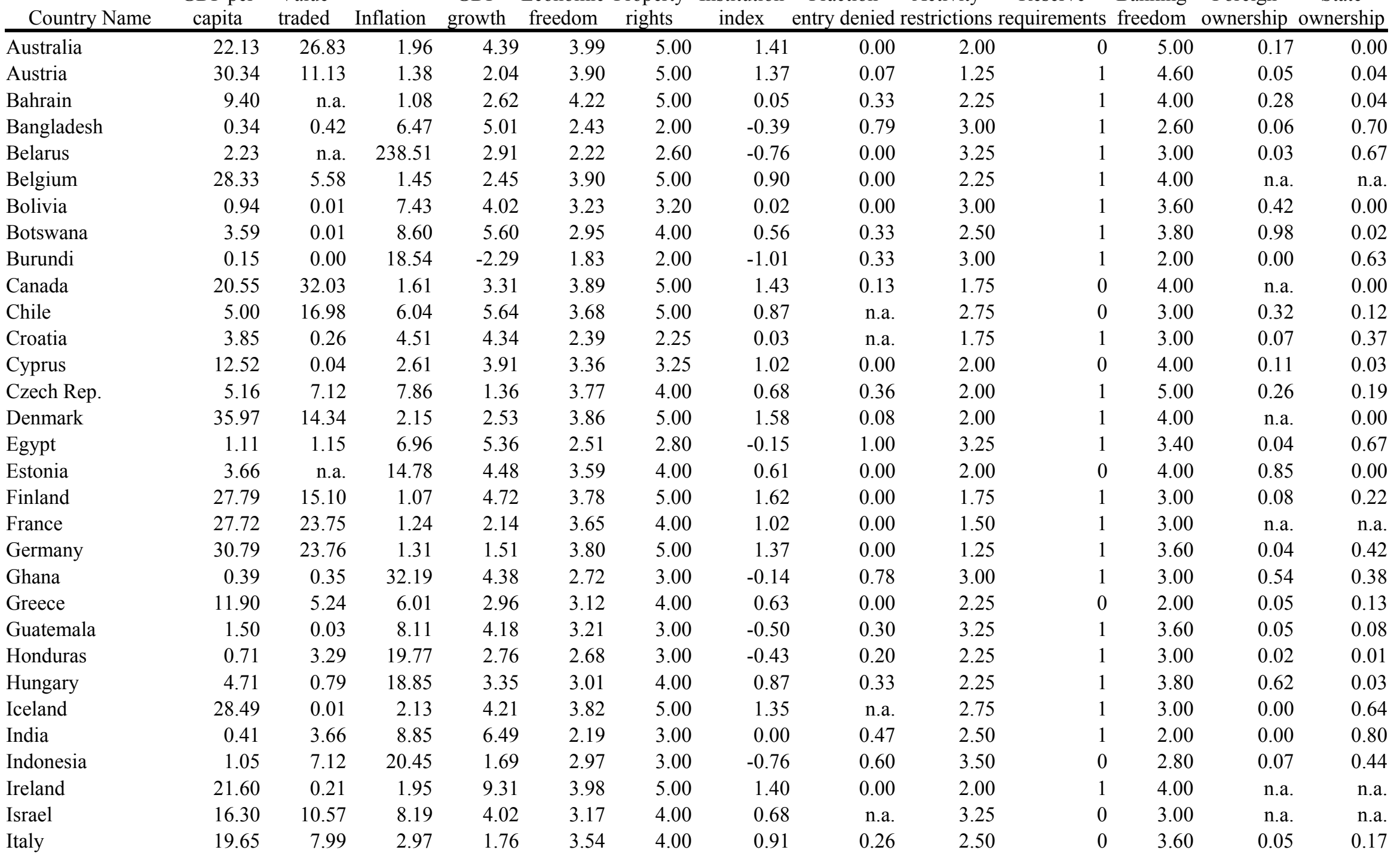


Table 2. (cont.)

KKZ

GDP per Value GDP Economic Property Institution Fraction Activity Reserve Banking Foreign State Country Name capita traded Inflation growth freedom rights index entry denied restrictions requirements freedom ownership ownership

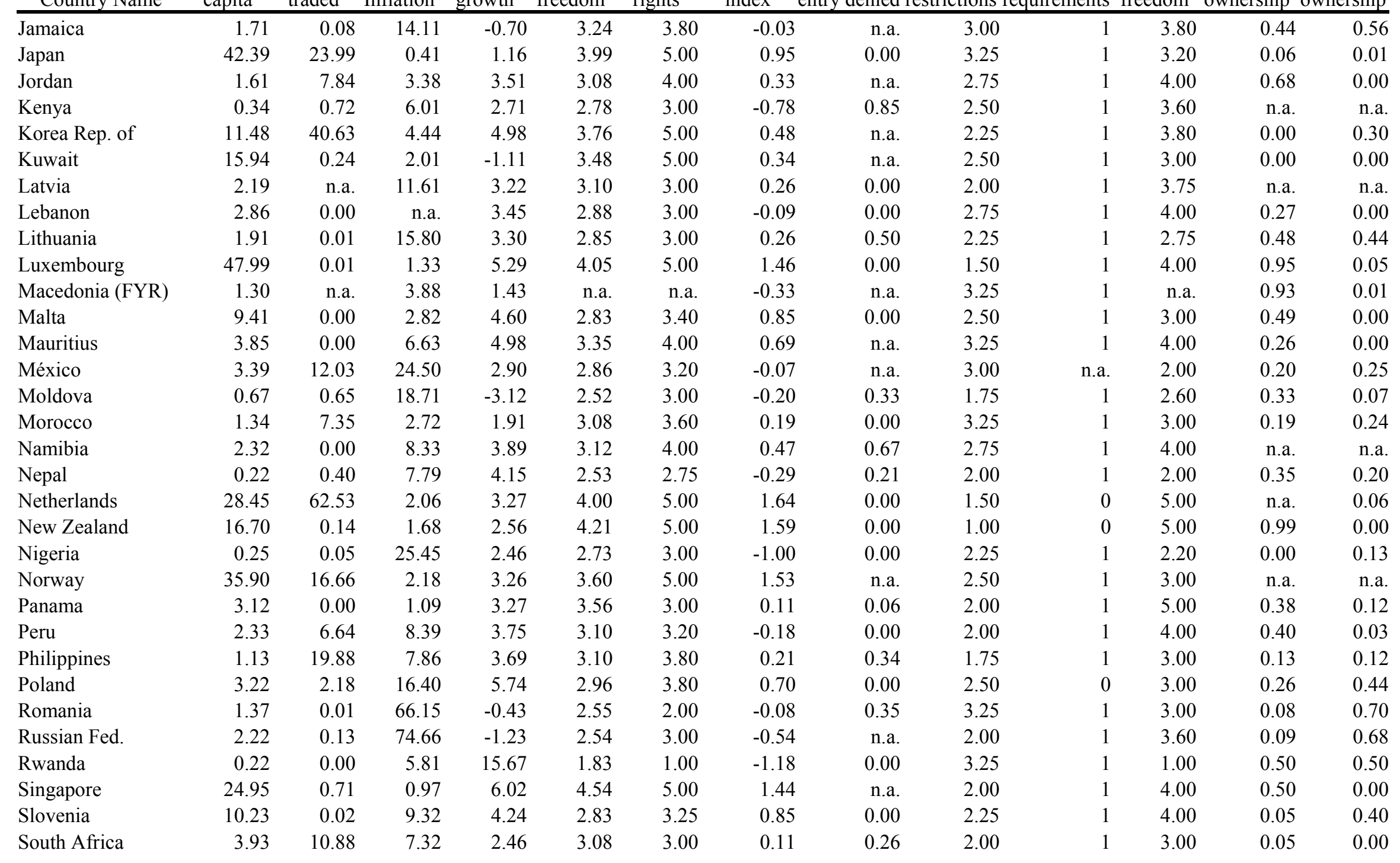




\begin{tabular}{|c|c|c|c|c|c|c|c|c|c|c|c|c|c|}
\hline Country Name & $\begin{array}{c}\text { GDP per } \\
\text { capita }\end{array}$ & $\begin{array}{l}\text { Value } \\
\text { traded } \\
\end{array}$ & Inflation & $\begin{array}{c}\text { GDP } \\
\text { growth }\end{array}$ & $\begin{array}{l}\text { Economic } \\
\text { freedom }\end{array}$ & $\begin{array}{c}\text { Property } \\
\text { rights } \\
\end{array}$ & $\begin{array}{c}\text { KKZ } \\
\text { Institution } \\
\text { index } \\
\end{array}$ & $\begin{array}{c}\text { Fraction } \\
\text { entry denied } 1 \\
\end{array}$ & $\begin{array}{c}\text { Activity } \\
\text { restrictions } \\
\end{array}$ & $\begin{array}{c}\text { Reserve } \\
\text { requirements }\end{array}$ & $\begin{array}{l}\text { Banking } \\
\text { freedom }\end{array}$ & $\begin{array}{c}\text { Foreign } \\
\text { ownership } \\
\end{array}$ & $\begin{array}{c}\text { State } \\
\text { ownership } \\
\end{array}$ \\
\hline Spain & 15.86 & 10.69 & 2.87 & 3.32 & 3.48 & 4.00 & 1.11 & 0.00 & 1.75 & 0 & 3.60 & 0.11 & 0.00 \\
\hline Sri Lanka & 0.77 & 1.70 & 9.45 & 4.94 & 3.26 & 3.00 & -0.38 & n.a. & 1.75 & 1 & 4.00 & n.a. & 0.55 \\
\hline Sweden & 28.26 & 40.29 & 0.77 & 2.70 & 3.49 & 4.00 & 1.53 & 0.07 & 2.25 & 0 & 3.60 & 0.02 & 0.00 \\
\hline Switzerland & 44.34 & 101.15 & 0.80 & 1.11 & 4.06 & 4.75 & 1.72 & 0.00 & 1.25 & 0 & 4.75 & 0.09 & 0.15 \\
\hline Taiwan & 13.76 & 147.23 & 1.91 & 5.87 & 4.05 & 5.00 & 0.89 & 0.07 & 3.00 & 1 & 3.00 & n.a. & 0.43 \\
\hline Thailand & 2.84 & 33.86 & 5.12 & 1.44 & 3.66 & 4.60 & 0.15 & 1.00 & 2.25 & 1 & 3.00 & 0.07 & 0.31 \\
\hline Trinidad \& Tobago & 4.53 & 0.03 & 4.25 & 4.48 & 3.40 & 5.00 & 0.59 & 0.25 & 2.25 & 0 & 4.00 & 0.08 & 0.15 \\
\hline United Kingdom & 20.19 & 92.16 & 2.79 & 2.72 & 4.13 & 5.00 & 1.50 & n.a. & 1.25 & 1 & 5.00 & n.a. & 0.00 \\
\hline US & 29.25 & 70.32 & 2.36 & 3.72 & 4.16 & 5.00 & 1.29 & 0.00 & 3.00 & 0 & 4.00 & 0.05 & 0.00 \\
\hline Weighted average & 22.50 & 0.35 & 4.37 & 3.02 & 3.65 & 4.38 & 0.93 & 0.09 & 2.25 & 0.60 & 3.66 & 0.13 & 0.16 \\
\hline
\end{tabular}

Notes: All variables are averages for the period 1995-99, except value traded for which we use year 1995 data. A detailed description of the definition and sources of the variables can be found in the Appendix. n.a. indicates not available. 
Table 3. Summary statistics and correlation matrix for entire sample by variable

Panel A Summary statistics

\begin{tabular}{|c|c|c|c|c|c|}
\hline Variable & Observations & Mean & Std. Dev. & Minimum & Maximum \\
\hline Net interest margin & 1,430 & 3.61 & 2.03 & 0.72 & 12.60 \\
\hline Bank concentration & 1,430 & 0.45 & 0.21 & 0.20 & 1.00 \\
\hline Bank concentration (Top-5) & 1,430 & 0.57 & 0.22 & 0.27 & 1.00 \\
\hline Bank concentration (All) & 1,430 & 0.41 & 0.20 & 0.18 & 0.97 \\
\hline Bank concentration (Deposits) & 1,330 & 0.46 & 0.24 & 0.12 & 1.00 \\
\hline Bank size & 1,430 & 7.04 & 2.02 & 1.74 & 13.49 \\
\hline Liquidity & 1,375 & 21.90 & 16.42 & 0.23 & 82.19 \\
\hline Bank equity & 1,429 & 9.18 & 6.97 & -0.77 & 78.76 \\
\hline Fee income & 1,426 & 0.90 & 1.52 & -6.39 & 13.80 \\
\hline Overhead & 1,430 & 3.02 & 1.65 & 0.64 & 10.18 \\
\hline Market share & 1,430 & 0.04 & 0.09 & 0.00 & 0.98 \\
\hline Bank risk & 1,430 & 0.64 & 1.12 & 0.00 & 11.52 \\
\hline GDP per capita & 1,430 & 22.50 & 14.25 & 0.15 & 47.99 \\
\hline Value traded & 1,409 & 0.35 & 0.35 & 0.00 & 1.47 \\
\hline Inflation & 1,402 & 4.37 & 9.05 & 0.41 & 238.51 \\
\hline GDP growth & 1,430 & 3.02 & 1.59 & -3.12 & 15.67 \\
\hline KKZ Institution index & 1,430 & 0.93 & 0.62 & -1.18 & 1.72 \\
\hline Economic freedom & 1,428 & 3.65 & 0.54 & 1.83 & 4.54 \\
\hline Property rights & 1,428 & 4.38 & 0.81 & 1.00 & 5.00 \\
\hline Fraction entry denied & 1,273 & 0.09 & 0.18 & 0.00 & 1.00 \\
\hline Activity restrictions & 1,430 & 2.25 & 0.73 & 1.00 & 3.50 \\
\hline Reserve requirements & 1,419 & 0.60 & 0.49 & 0.00 & 1.00 \\
\hline Banking freedom & 1,428 & 3.66 & 0.73 & 1.00 & 5.00 \\
\hline Foreign ownership & 1,093 & 0.13 & 0.20 & 0.00 & 0.99 \\
\hline State ownership & 1,258 & 0.16 & 0.22 & 0.00 & 0.80 \\
\hline
\end{tabular}

Notes: All country-level variables are averages for the period 1995-99, except Bank concentration (Deposits) for which we use data for the year 1999. All bankspecific variables are year 1995 data, except net interest margins, overhead ratios and bank risk for which we use averages for the period 1995-99. A detailed description of the definition and sources of the variables can be found in the Appendix. 


\begin{tabular}{|c|c|c|c|c|c|c|c|c|c|c|}
\hline & $\begin{array}{c}\text { Net interest } \\
\text { margin }\end{array}$ & $\begin{array}{c}\text { Bank } \\
\text { concentration }\end{array}$ & Bank size & Liquidity & Bank equity & Fee income & $\begin{array}{c}\text { GDP per } \\
\text { capita }\end{array}$ & $\begin{array}{l}\text { Value } \\
\text { traded }\end{array}$ & Inflation & GDP growth \\
\hline Net interest margin & 1.000 & & & & & & & & & \\
\hline Bank concentration & $* * 0.083$ & 1.000 & & & & & & & & \\
\hline Liquidity & $* *_{-} 0.053$ & $* * 0.143$ & $* *-0.175$ & 1.000 & & & & & & \\
\hline Bank equity & $* * 0.247$ & $* * 0.186$ & $* *-0.454$ & $* * 0.083$ & 1.000 & & & & & \\
\hline Fee income & 0.012 & $* * 0.155$ & $* *-0.109$ & $* * 0.153$ & $* * 0.186$ & 1.000 & & & & \\
\hline Value traded & $* *-0.207$ & $* *-0.139$ & $* * 0.146$ & $* *-0.191$ & $* * 0.057$ & 0.008 & $* * 0.418$ & 1.000 & & \\
\hline Inflation & $* * 0.382$ & $* * 0.180$ & $* *-0.202$ & $* * 0.164$ & $* * 0.112$ & $* * 0.107$ & $* *-0.444$ & $* *-0.309$ & 1.000 & \\
\hline GDP growth & $* * 0.163$ & $* *-0.069$ & -0.050 & $* * 0.067$ & 0.020 & $* *-0.114$ & $* *-0.456$ & -0.012 & 0.046 & 1.000 \\
\hline KKZ Institution index & $* *-0.426$ & $* *-0.104$ & $* * 0.220$ & $* *-0.232$ & $* *-0.082$ & $* * 0.006$ & $* * 0.804$ & $* * 0.533$ & $* *-0.485$ & $* *-0.232$ \\
\hline Economic freedom & $* *-0.339$ & $* *-0.267$ & $* * 0.301$ & $* *-0.327$ & $* *-0.118$ & $* *-0.077$ & $* * 0.775$ & $* * 0.636$ & $* *-0.463$ & $* *-0.307$ \\
\hline Property rights & $* *-0.376$ & $* *-0.237$ & $* * 0.355$ & $* *-0.260$ & $* *-0.159$ & $* *-0.089$ & $* * 0.754$ & $* * 0.547$ & $* *-0.435$ & $* *-0.224$ \\
\hline Fraction entry denied & $* * 0.210$ & $* * 0.189$ & $* *-0.144$ & $* * 0.161$ & 0.040 & 0.009 & $* *-0.617$ & $* *-0.348$ & $* * 0.309$ & $* * 0.218$ \\
\hline Activity restrictions & $* * 0.274$ & $* *-0.316$ & $* * 0.146$ & $* *-0.181$ & $* *-0.090$ & $* *-0.212$ & $* *-0.183$ & -0.006 & $* * 0.160$ & $* * 0.259$ \\
\hline Reserve requirements & -0.035 & 0.042 & -0.020 & $* * 0.141$ & $* *-0.052$ & 0.022 & $* *-0.173$ & $* *_{-} 0.401$ & $* * 0.068$ & -0.038 \\
\hline Banking freedom & $* *-0.167$ & $* * 0.154$ & -0.028 & $* *-0.067$ & 0.036 & $* * 0.079$ & $* * 0.386$ & $* * 0.445$ & $* *-0.232$ & $* *-0.233$ \\
\hline Foreign ownership & 0.046 & $* * 0.235$ & $* *-0.137 *$ & $* * 0.137$ & 0.008 & 0.011 & $* *-0.109$ & $* *-0.296$ & $* * 0.066$ & $* * 0.240$ \\
\hline State ownership & 0.009 & $* * 0.070$ & $* *-0.143 *$ & $* * 0.254$ & 0.054 & $* * 0.070$ & $* *-0.395$ & $* *-0.213$ & $* * 0.299$ & $* * 0.237$ \\
\hline
\end{tabular}




\begin{tabular}{|c|c|c|c|c|c|c|c|c|c|}
\hline & $\begin{array}{c}\text { KKZ } \\
\text { Institution } \\
\text { index }\end{array}$ & $\begin{array}{l}\text { Economic } \\
\text { freedom }\end{array}$ & $\begin{array}{c}\text { Property } \\
\text { rights }\end{array}$ & $\begin{array}{c}\text { Fraction } \\
\text { entry denied }\end{array}$ & $\begin{array}{l}\text { Activity } \\
\text { restrictions }\end{array}$ & $\begin{array}{c}\text { Reserve } \\
\text { requirements }\end{array}$ & $\begin{array}{l}\text { Banking } \\
\text { freedom }\end{array}$ & $\begin{array}{c}\text { Foreign } \\
\text { ownership }\end{array}$ & $\begin{array}{c}\text { State } \\
\text { ownership }\end{array}$ \\
\hline KKZ Institution index & 1.000 & & & & & & & & \\
\hline Economic freedom & $* * 0.803$ & 1.000 & & & & & & & \\
\hline Property rights & $* * 0.825$ & $* * 0.904$ & 1.000 & & & & & & \\
\hline Fraction entry denied & $* *-0.629$ & $* *_{-} 0.630$ & $* *-0.560$ & 1.000 & & & & & \\
\hline Activity restrictions & $* *-0.380$ & $* *-0.066$ & $* *_{-} 0.071$ & $* * 0.194$ & 1.000 & & & & \\
\hline Reserve requirements & $* *-0.338$ & $* *_{-}-0.332$ & $* *-0.249$ & $* * 0.154$ & $* *-0.205$ & 1.000 & & & \\
\hline Banking freedom & $* * 0.589$ & $* * 0.629$ & $* * 0.500$ & $* *-0.377$ & $* *-0.305$ & $* *-0.329$ & 1.000 & & \\
\hline Foreign ownership & -0.044 & -0.043 & $* *-0.069$ & -0.024 & $* *-0.149$ & $* * 0.198$ & $* * 0.174$ & 1.000 & \\
\hline State ownership & $* *-0.409$ & $* *-0.613$ & $* *-0.454$ & $* * 0.538$ & $* *-0.122$ & $* * 0.322$ & $* *-0.556$ & $* *-0.215$ & 1.000 \\
\hline
\end{tabular}

Notes: All country-level variables are averages for the period 1995-99, except Bank concentration (Deposits) for which we use data for the year 1999. All bankspecific variables are year 1995 data, except net interest margins, overhead ratios and bank risk for which we use averages for the period 1995-99. A detailed description of the definition and sources of the variables can be found in the Appendix. ** indicates significance at a $5 \%$ level. 
Table 4. Regression results controlling for bank regulatory environment

\begin{tabular}{|c|c|c|c|c|}
\hline & $(1)$ & (2) & (3) & $(4)$ \\
\hline Bank concentration & $\begin{array}{r}* * 2.782 \\
(1.313)\end{array}$ & $\begin{array}{r}* * 2.326 \\
(1.055)\end{array}$ & $\begin{array}{r}* * 2.584 \\
(1.141)\end{array}$ & $\begin{array}{r}* * 2.206 \\
(1.108)\end{array}$ \\
\hline Bank size & $\begin{array}{r}* * *_{-} 0.179 \\
(0.024)\end{array}$ & $\begin{array}{r}* * *-0.182 \\
(0.024)\end{array}$ & $\begin{array}{r}* * *-0.185 \\
(0.023)\end{array}$ & $\begin{array}{r}* * *-0.180 \\
(0.024)\end{array}$ \\
\hline Liquidity & $\begin{array}{r}* * *_{-} 0.015 \\
(0.003)\end{array}$ & $\begin{array}{r}* * *-0.018 \\
(0.003)\end{array}$ & $\begin{array}{r}* * *_{-}-0.017 \\
(0.003)\end{array}$ & $\begin{array}{r}* * *-0.019 \\
(0.003)\end{array}$ \\
\hline Bank equity & $\begin{array}{r}* * 0.015 \\
(0.006)\end{array}$ & $\begin{array}{r}* * * 0.024 \\
(0.006)\end{array}$ & $\begin{array}{r}* * * 0.019 \\
(0.006)\end{array}$ & $\begin{array}{r}* * * 0.024 \\
\quad(0.006)\end{array}$ \\
\hline Fee income & $\begin{array}{r}* *_{-} 0.065 \\
(0.026)\end{array}$ & $\begin{array}{r}-0.024 \\
(0.026)\end{array}$ & $\begin{array}{l}-0.034 \\
(0.026)\end{array}$ & $\begin{array}{r}-0.029 \\
(0.026)\end{array}$ \\
\hline Fraction of entry denied & $\begin{array}{r}* * 2.760 \\
(1.155)\end{array}$ & - & - & 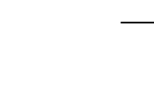 \\
\hline Activity restrictions & - & $\begin{array}{r}* * * 1.366 \\
(0.378)\end{array}$ & - & - \\
\hline Reserve requirements & - & - & $\begin{array}{l}* 1.036 \\
(0.577)\end{array}$ & - \\
\hline Banking freedom & - & - & - & $\begin{array}{r}* * *-0.963 \\
(0.294)\end{array}$ \\
\hline R2-within & 0.096 & 0.107 & 0.101 & 0.107 \\
\hline R2-between & 0.209 & 0.232 & 0.165 & 0.221 \\
\hline No. observations & 1217 & 1372 & 1362 & 1371 \\
\hline No. countries & 55 & 71 & 69 & 70 \\
\hline
\end{tabular}

Notes: Dependent variable is net interest margin. All country-level variables are averages for the period 1995-99. All bank-specific variables are year 1995 data, except net interest margins for which we use averages for the period 1995-99. A detailed description of the definition and sources of the variables can be found in the Appendix. We use GLS with random country effects. A constant term was included, but is not reported. $*, * *, * * *$ indicate significance levels of 10,5 , and 1 percent respectively. 
Table 5. Regression results controlling for macro environment

\begin{tabular}{|c|c|c|c|c|c|}
\hline & (1) & (2) & (3) & $(4)$ & (5) \\
\hline Bank concentration & $\begin{array}{r}* * 2.314 \\
(1.080)\end{array}$ & $\begin{array}{r}* * * 2.889 \\
(1.122)\end{array}$ & $\begin{array}{r}1.834 \\
(1.164)\end{array}$ & $\begin{array}{r}* * 2.727 \\
(1.150)\end{array}$ & $\begin{array}{l}* 2.066 \\
(1.140)\end{array}$ \\
\hline Bank size & $\begin{array}{r}* * *-0.179 \\
(0.024)\end{array}$ & $\begin{array}{r}* * *-0.181 \\
(0.024)\end{array}$ & $\begin{array}{r}* * *-0.177 \\
(0.023)\end{array}$ & $\begin{array}{r}* * *-0.162 \\
(0.024)\end{array}$ & $\begin{array}{r}* * *-0.155 \\
(0.024)\end{array}$ \\
\hline Liquidity & $\begin{array}{r}* * *_{-} 0.019 \\
(0.003)\end{array}$ & $\begin{array}{r}* * *_{-}-0.018 \\
(0.003)\end{array}$ & $\begin{array}{r}* * *_{-} 0.020 \\
(0.003)\end{array}$ & $\begin{array}{r}* * *_{-}-0.020 \\
(0.003)\end{array}$ & $\begin{array}{r}* * *-0.021 \\
(0.003)\end{array}$ \\
\hline Bank equity & $\begin{array}{r}* * * 0.022 \\
(0.006)\end{array}$ & $\begin{array}{r}* * * 0.024 \\
(0.006)\end{array}$ & $\begin{array}{r}* * * 0.024 \\
(0.006)\end{array}$ & $\begin{array}{r}* * * 0.025 \\
\quad(0.006)\end{array}$ & $\begin{array}{r}* * * 0.024 \\
(0.006)\end{array}$ \\
\hline Fee income & $\begin{array}{r}-0.024 \\
(0.026)\end{array}$ & $\begin{array}{r}-0.031 \\
(0.026)\end{array}$ & $\begin{array}{r}0.001 \\
(0.027)\end{array}$ & $\begin{array}{r}0.006 \\
(0.027)\end{array}$ & $\begin{array}{r}0.010 \\
(0.027)\end{array}$ \\
\hline Inflation & $\begin{array}{r}* * * 0.041 \\
(0.009)\end{array}$ & - & - & - & $\begin{array}{r}* * * 0.090 \\
(0.023)\end{array}$ \\
\hline GDP growth & - & $\begin{array}{l}*_{-} 0.202 \\
(0.104)\end{array}$ & - & 一 & $\begin{array}{r}-0.024 \\
(0.108)\end{array}$ \\
\hline Total value traded & - & - & $\begin{array}{r}* * *-2.847 \\
(0.906)\end{array}$ & - & $\begin{array}{r}*_{-}-1.640 \\
(0.889)\end{array}$ \\
\hline State ownership & - & - & - & $\begin{array}{r}* * 2.559 \\
(1.108)\end{array}$ & $\begin{array}{r}-0.432 \\
(1.219)\end{array}$ \\
\hline R2-within & 0.106 & 0.107 & 0.110 & 0.113 & 0.114 \\
\hline R2-between & 0.293 & 0.165 & 0.237 & 0.196 & 0.461 \\
\hline No. observations & 1344 & 1372 & 1352 & 1206 & 1168 \\
\hline No. countries & 70 & 71 & 66 & 63 & 58 \\
\hline
\end{tabular}

Notes: Dependent variable is net interest margin. All country-level variables are averages for the period 1995-99, except total value traded for which we use 1995 data. All bank-specific variables are year 1995 data, except net interest margins for which we use averages for the period 1995-99. For more details on the definition and source of the variables, see the Appendix. Results estimated using GLS with random country effects. A constant term was included, but is not reported. *, ${ }^{*}, * * *$ indicate significance levels of 10,5 , and 1 percent respectively. 


\section{Table 6. Regression results controlling for macro and regulatory environment}

\begin{tabular}{|c|c|c|c|c|}
\hline & (1) & (2) & (3) & (4) \\
\hline Bank concentration & $\begin{array}{r}1.923 \\
(1.226)\end{array}$ & $\begin{array}{l}* 1.971 \\
(1.029)\end{array}$ & $\begin{array}{c}* 2.046 \\
(1.088)\end{array}$ & $\begin{array}{r}* 1.840 \\
(1.057)\end{array}$ \\
\hline Bank size & $\begin{array}{r}* * *_{-}-0.178 \\
(0.024)\end{array}$ & $\begin{array}{r}* * *_{-} 0.180 \\
(0.024)\end{array}$ & $\begin{array}{r}* * *-0.183 \\
(0.024)\end{array}$ & $\begin{array}{r}* * *-0.178 \\
(0.024)\end{array}$ \\
\hline Liquidity & $\begin{array}{r}* * *-0.016 \\
(0.003)\end{array}$ & $\begin{array}{r}* * *_{-} 0.019 \\
(0.003)\end{array}$ & $\begin{array}{r}* * *-0.018 \\
(0.003)\end{array}$ & $\begin{array}{r}* * *-0.020 \\
(0.003)\end{array}$ \\
\hline Bank equity & $\begin{array}{l}* 0.013 \\
(0.006)\end{array}$ & $\begin{array}{r}* * * 0.022 \\
(0.006)\end{array}$ & $\begin{array}{r}* * * 0.017 \\
(0.006)\end{array}$ & $\begin{array}{r}* * * 0.022 \\
(0.006)\end{array}$ \\
\hline Fee income & $\begin{array}{r}*_{-} 0.058 \\
(0.006)\end{array}$ & $\begin{array}{r}-0.020 \\
(0.026)\end{array}$ & $\begin{array}{r}-0.030 \\
(0.026)\end{array}$ & $\begin{array}{l}-0.024 \\
(0.026)\end{array}$ \\
\hline Inflation & $\begin{array}{r}* * * 0.039 \\
(0.009)\end{array}$ & $\begin{array}{r}* * * 0.036 \\
(0.009)\end{array}$ & $\begin{array}{r}* * * 0.040 \\
(0.009)\end{array}$ & $\begin{array}{r}* * * 0.038 \\
(0.009)\end{array}$ \\
\hline Fraction of entry denied & $\begin{array}{r}* * * 2.718 \\
(1.052)\end{array}$ & - & - & - \\
\hline Activity restrictions & - & $\begin{array}{r}* * * 1.008 \\
(0.373)\end{array}$ & - & - \\
\hline Reserve requirements & & & $\begin{array}{r}0.737 \\
(0.542)\end{array}$ & - \\
\hline Banking freedom & - & - & - & $\begin{array}{r}* * *-0.774 \\
\quad(0.279)\end{array}$ \\
\hline R2-within & 0.095 & 0.106 & 0.099 & 0.106 \\
\hline R2-between & 0.382 & 0.349 & 0.330 & 0.374 \\
\hline No. observations & 1189 & 1344 & 1334 & 1343 \\
\hline No. countries & 54 & 70 & 68 & 69 \\
\hline
\end{tabular}

Notes: Dependent variable is net interest margin. All country-level variables are averages for the period 1995-99. All bank-specific variables are year 1995 data, except net interest margins for which we use averages for the period 1995-99. For more details on the definition and source of the variables, see the Appendix. We use GLS with random country effects. A constant term was included, but is not reported. *, **,*** indicate significance levels of 10,5 , and 1 percent respectively. 
Table 7. Regression results controlling for institutional environment

\begin{tabular}{|c|c|c|c|c|}
\hline & $(1)$ & $(2)$ & (3) & (4) \\
\hline \multirow[t]{2}{*}{ Bank concentration } & 0.939 & 1.571 & 0.929 & 1.214 \\
\hline & $(1.027)$ & $(0.970)$ & $(1.045)$ & (1.057) \\
\hline \multirow[t]{2}{*}{ Bank size } & $* * *-0.174$ & $* * *-0.172$ & $* * *-0.170$ & $* * *-0.170$ \\
\hline & $(0.024)$ & $(0.024)$ & $(0.024)$ & $(0.024)$ \\
\hline \multirow[t]{2}{*}{ Liquidity } & $* * *_{-} 0.019$ & $* * *_{-}-0.020$ & $* * *_{-}-0.020$ & $* * *-0.020$ \\
\hline & $(0.003)$ & $(0.003)$ & $(0.003)$ & $(0.003)$ \\
\hline \multirow[t]{2}{*}{ Bank equity } & $* * * 0.022$ & $* * * 0.022$ & $* * * 0.023$ & $* * * 0.022$ \\
\hline & $(0.006)$ & $(0.006)$ & $(0.006)$ & $(0.006)$ \\
\hline \multirow[t]{2}{*}{ Fee income } & -0.023 & -0.024 & -0.027 & -0.027 \\
\hline & $(0.026)$ & $(0.026)$ & $(0.026)$ & $(0.026)$ \\
\hline \multirow[t]{2}{*}{ Inflation } & $* * * 0.031$ & $* * * 0.023$ & $* * * 0.025$ & $* * * 0.028$ \\
\hline & $(0.008)$ & $(0.009)$ & $(0.009)$ & $(0.009)$ \\
\hline GDP per capita & $* * *-0.088$ & - & - & - \\
\hline KKZ Institution index & - & $\begin{array}{r}* * *-1.797 \\
(0.301)\end{array}$ & - & - \\
\hline Economic freedom & - & - & $\begin{array}{r}* * *-2.046 \\
(0.415)\end{array}$ & 一 \\
\hline Property rights & - & - & - & $\begin{array}{r}* * *-1.132 \\
(0.249)\end{array}$ \\
\hline R2-within & 0.106 & 0.106 & 0.107 & 0.107 \\
\hline R2-between & 0.475 & 0.540 & 0.503 & 0.475 \\
\hline No. observations & 1344 & 1344 & 1343 & 1343 \\
\hline No. countries & 70 & 70 & 69 & 69 \\
\hline
\end{tabular}

Notes: Dependent variable is net interest margin. All country-level variables are averages for the period $1995-99$. All bank-specific variables are year 1995 data, except net interest margins for which we use averages for the period 1995-99. For more details on the definition and source of the variables, see the Appendix. We use GLS with random country effects. A constant term was included, but is not reported. ***, *** indicate significance levels of 10, 5, and 1 percent respectively. 
Table 8. Regression results controlling for macro, regulatory, and institutional environment

\begin{tabular}{lrrr}
\hline & $(1)$ & $(2)$ & $(3)$ \\
\hline Bank concentration & 1.159 & 1.152 & 1.228 \\
& $(1.206)$ & $(1.031)$ & $(1.058)$ \\
Bank size & $* * *-0.171$ & $* * *-0.171$ & $* * *-0.170$ \\
Liquidity & $(0.024)$ & $(0.024)$ & $(0.024)$ \\
& $* * *-0.017$ & $* * *-0.020$ & $* * *-0.020$ \\
Bank equity & $(0.003)$ & $(0.003)$ & $(0.003)$ \\
& $* * * 0.013$ & $* * * 0.022$ & $* * * 0.022$ \\
Fee income & $(0.006)$ & $(0.006)$ & $(0.006)$ \\
& $* *-0.058$ & -0.025 & -0.027 \\
Inflation & $(0.026)$ & $(0.026)$ & $(0.026)$ \\
& $* * * 0.028$ & $* * * 0.027$ & $* * * 0.028$ \\
Property rights & $(0.009)$ & $(0.009)$ & $(0.009)$ \\
& $* * *-1.114$ & $* * *-1.048$ & $* * *-1.037$ \\
Fraction of entry denied & $(0.296)$ & $(0.253)$ & $(0.286)$ \\
& 1.503 & - & - \\
Activity restrictions & $(1.069)$ & & - \\
Banking freedom & - & 0.449 & -0.213 \\
& - & - & $(0.316)$ \\
R2-within & & & 0.107 \\
R2-between & 0.095 & 0.107 & 0.478 \\
No. observations & 0.504 & 0.483 & 1343 \\
No. countries & 1189 & 1343 & 69 \\
\hline
\end{tabular}

Notes: Dependent variable is net interest margin. All country-level variables are averages for the period 1995-99. All bank-specific variables are year 1995 data, except net interest margins for which we use averages for the period 1995-99. For more details on the definition and source of the variables, see the Appendix. We use GLS with random country effects. A constant term was included, but is not reported. *, **,*** indicate significance levels of 10, 5 , and 1 percent respectively. 
Table 9. Regression results using alternative bank concentration measures and controlling for regulations

\begin{tabular}{|c|c|c|c|c|c|c|c|c|c|}
\hline & $(1)$ & $(2)$ & (3) & $(4)$ & $(5)$ & $(6)$ & $(7)$ & $(8)$ & $(9)$ \\
\hline Bank concentration (Top-5) & $\begin{array}{r}1.386 \\
(1.238)\end{array}$ & $\begin{array}{r}1.423 \\
(1.078)\end{array}$ & $\begin{array}{r}1.482 \\
(1.106)\end{array}$ & - & - & - & - & - & - \\
\hline Bank concentration (All) & - & - & - & $\begin{array}{r}0.875 \\
(1.257)\end{array}$ & $\begin{array}{r}0.827 \\
(1.078)\end{array}$ & $\begin{array}{r}0.891 \\
(1.107)\end{array}$ & 一 & 一 & - \\
\hline Bank concentration (Deposits) & - & - & 一 & - & - & - & $\begin{array}{r}0.889 \\
(1.189)\end{array}$ & $\begin{array}{r}0.998 \\
(1.161)\end{array}$ & $\begin{array}{r}1.006 \\
(1.200)\end{array}$ \\
\hline Bank size & $\begin{array}{r}* * *-0.171 \\
(0.024)\end{array}$ & $\begin{array}{r}* * *-0.171 \\
(0.024)\end{array}$ & $\begin{array}{r}* * *-0.170 \\
(0.024)\end{array}$ & $\begin{array}{r}* * *-0.171 \\
(0.024)\end{array}$ & $\begin{array}{r}* * *-0.171 \\
(0.024)\end{array}$ & $\begin{array}{r}* * *-0.170 \\
(0.024)\end{array}$ & $\begin{array}{r}* * *-0.180 \\
(0.024)\end{array}$ & $\begin{array}{r}* * *-0.183 \\
(0.024)\end{array}$ & $\begin{array}{r}* * *-0.183 \\
(0.024)\end{array}$ \\
\hline Liquidity & $\begin{array}{r}* * *-0.017 \\
(0.003)\end{array}$ & $\begin{array}{r}* * *-0.020 \\
(0.003)\end{array}$ & $\begin{array}{r}* * *-0.020 \\
(0.003)\end{array}$ & $\begin{array}{r}* * *-0.017 \\
(0.003)\end{array}$ & $\begin{array}{r}* * *-0.020 \\
(0.003)\end{array}$ & $\begin{array}{r}* * *-0.020 \\
(0.003)\end{array}$ & $\begin{array}{r}* * *-0.018 \\
(0.003)\end{array}$ & $\begin{array}{r}* * *-0.019 \\
(0.003)\end{array}$ & $\begin{array}{r}* * *_{-} 0.019 \\
(0.003)\end{array}$ \\
\hline Bank equity & $\begin{array}{r}* * 0.013 \\
(0.006)\end{array}$ & $\begin{array}{r}* * * 0.022 \\
(0.006)\end{array}$ & $\begin{array}{r}* * * 0.022 \\
(0.006)\end{array}$ & $\begin{array}{r}* * 0.013 \\
(0.006)\end{array}$ & $\begin{array}{r}* * * 0.022 \\
(0.006)\end{array}$ & $\begin{array}{r}* * * 0.022 \\
(0.006)\end{array}$ & $\begin{array}{r}0.010 \\
(0.006)\end{array}$ & $\begin{array}{r}* * * 0.022 \\
(0.006)\end{array}$ & $\begin{array}{r}* * * 0.022 \\
(0.006)\end{array}$ \\
\hline Fee income & $\begin{array}{r}* *_{-} 0.058 \\
(0.026)\end{array}$ & $\begin{array}{r}-0.025 \\
(0.026)\end{array}$ & $\begin{array}{r}-0.027 \\
(0.026)\end{array}$ & $\begin{array}{r}* *_{-} 0.058 \\
(0.026)\end{array}$ & $\begin{array}{r}-0.025 \\
(0.026)\end{array}$ & $\begin{array}{r}-0.027 \\
(0.026)\end{array}$ & $\begin{array}{r}-0.027 \\
(0.029)\end{array}$ & $\begin{array}{r}-0.022 \\
(0.029)\end{array}$ & $\begin{array}{r}-0.024 \\
(0.029)\end{array}$ \\
\hline Inflation & $\begin{array}{r}* * * 0.028 \\
(0.009)\end{array}$ & $\begin{array}{r}* * * 0.027 \\
(0.009)\end{array}$ & $\begin{array}{r}* * * 0.028 \\
(0.009)\end{array}$ & $\begin{array}{r}* * * 0.028 \\
(0.009)\end{array}$ & $\begin{array}{r}* * * 0.027 \\
(0.009)\end{array}$ & $\begin{array}{r}* * * 0.028 \\
(0.009)\end{array}$ & $\begin{array}{r}* * * 0.029 \\
(0.010)\end{array}$ & $\begin{array}{r}* * * 0.026 \\
(0.009)\end{array}$ & $\begin{array}{r}* * * 0.028 \\
\quad(0.010)\end{array}$ \\
\hline Property rights & $\begin{array}{r}* * *-1.123 \\
(0.294)\end{array}$ & $\begin{array}{r}* * *-1.055 \\
(0.251)\end{array}$ & $\begin{array}{r}* * *-1.049 \\
(0.283)\end{array}$ & $\begin{array}{r}* * *-1.131 \\
(0.296)\end{array}$ & $\begin{array}{r}* * *-1.059 \\
(0.254)\end{array}$ & $\begin{array}{r}* * *-1.053 \\
(0.287)\end{array}$ & $\begin{array}{r}* * *-1.123 \\
(0.311)\end{array}$ & $\begin{array}{r}* * *-1.049 \\
(0.298)\end{array}$ & $\begin{array}{r}* * *-1.034 \\
(0.347)\end{array}$ \\
\hline Fraction of entry denied & $\begin{array}{r}1.455 \\
(1.071)\end{array}$ & - & - & $\begin{array}{r}1.509 \\
(1.072)\end{array}$ & - & - & $\begin{array}{r}1.673 \\
(1.126)\end{array}$ & - & - \\
\hline Activity restrictions & - & $\begin{array}{r}0.450 \\
(0.387)\end{array}$ & - & - & $\begin{array}{r}0.456 \\
(0.389)\end{array}$ & 一 & - & $\begin{array}{r}0.510 \\
(0.448)\end{array}$ & - \\
\hline Banking freedom & - & - & $\begin{array}{r}-0.207 \\
(0.315)\end{array}$ & - & - & $\begin{array}{r}-0.206 \\
(0.317)\end{array}$ & - & - & $\begin{array}{l}-0.255 \\
(0.377)\end{array}$ \\
\hline R2-within & 0.095 & 0.107 & 0.107 & 0.095 & 0.107 & 0.107 & 0.099 & 0.114 & 0.114 \\
\hline R2-between & 0.508 & 0.487 & 0.482 & 0.501 & 0.479 & 0.473 & 0.508 & 0.461 & 0.454 \\
\hline No. observations & 1189 & 1343 & 1343 & 1189 & 1343 & 1343 & 1159 & 1247 & 1247 \\
\hline No. countries & 54 & 69 & 69 & 54 & 69 & 69 & 50 & 59 & 59 \\
\hline
\end{tabular}

Notes: Dependent variable is net interest margin. All country-level variables are averages for the period 1995-99, except Bank concentration (Deposits) for which we use data for the year 1999. All bank-specific variables are year 1995 data, except net interest margins for which we use averages for the period 199599. For more details on the definition and source of the variables, see the Appendix. We use GLS with random country effects. A constant term was included, but is not reported. $*, * *, * *$ indicate significance levels of 10,5 , and 1 percent respectively. 
Table 10. Regression results controlling for high concentration, institutions and regulatory restrictions

\begin{tabular}{|c|c|c|c|}
\hline \multirow{3}{*}{ Bank concentration } & \multicolumn{3}{|c|}{ High concentration } \\
\hline & (1) & (2) & (3) \\
\hline & $\begin{array}{r}1.409 \\
(1.537)\end{array}$ & $\begin{array}{r}1.233 \\
(1.412)\end{array}$ & $\begin{array}{r}1.154 \\
(1.454)\end{array}$ \\
\hline High bank concentration & 0.183 & -0.021 & -0.242 \\
\hline Bank size & $\begin{array}{r}(2.450) \\
* * *-0.171\end{array}$ & $\begin{array}{r}(2.088) \\
* * *-0.171\end{array}$ & $\begin{array}{r}(2.159) \\
* * *-0.170\end{array}$ \\
\hline Liquidity & $\begin{array}{r}* * *_{-}-0.017 \\
(0.003)\end{array}$ & $\begin{array}{r}* * *_{-}-0.020 \\
(0.003)\end{array}$ & $\begin{array}{r}* * * 0.020 \\
(0.003)\end{array}$ \\
\hline Bank equity & $\begin{array}{r}* * 0.013 \\
(0.006)\end{array}$ & $\begin{array}{r}* * * 0.022 \\
(0.006)\end{array}$ & $\begin{array}{r}* * * 0.022 \\
(0.006)\end{array}$ \\
\hline Fee income & $\begin{array}{r}* *-0.058 \\
(0.026)\end{array}$ & $\begin{array}{r}-0.025 \\
(0.026)\end{array}$ & $\begin{array}{r}-0.027 \\
(0.026)\end{array}$ \\
\hline Inflation & $\begin{array}{r}* * * 0.028 \\
(0.010)\end{array}$ & $\begin{array}{r}* * 0.025 \\
(0.009)\end{array}$ & $\begin{array}{r}* * 0.028 \\
(0.009)\end{array}$ \\
\hline Property rights & $\begin{array}{r}* * *-1.084 \\
(0.351)\end{array}$ & $\begin{array}{r}* * *-1.046 \\
(0.290)\end{array}$ & $\begin{array}{r}* * *-1.055 \\
(0.311)\end{array}$ \\
\hline Property rights * high bank concentration & $\begin{array}{r}-0.115 \\
(0.634)\end{array}$ & $\begin{array}{r}-0.010 \\
(0.518)\end{array}$ & $\begin{array}{r}0.079 \\
(0.539)\end{array}$ \\
\hline Fraction of entry denied & $\begin{array}{r}1.550 \\
(1.121)\end{array}$ & - & - \\
\hline Activity restrictions & - & $\begin{array}{r}0.451 \\
(0.397)\end{array}$ & - \\
\hline Banking freedom & - & - & $\begin{array}{r}-0.224 \\
(0.329)\end{array}$ \\
\hline R2-within & 0.095 & 0.107 & 0.107 \\
\hline R2-between & 0.505 & 0.483 & 0.493 \\
\hline No. observations & 1189 & 1343 & 1343 \\
\hline No. countries & 54 & 69 & 69 \\
\hline
\end{tabular}

Notes: Dependent variable is net interest margin. All country-level variables are averages for the period 1995-99. All bank-specific variables are year 1995 data, except net interest margin for which we use averages for the period 1995-99. For more details on the definition and source of the variables, see the Appendix. High bank concentration is a dummy variable that takes value of one if the country has a concentration ratio of more than 80 percent, and zero otherwise. We use GLS with random country effects. A constant term was included, but is not reported. *, **, *** indicate significance levels of 10,5 , and 1 percent respectively. 
Table 11. Regression results using an alternative efficiency measure and controlling for institutions and regulatory restrictions

\begin{tabular}{|c|c|c|c|}
\hline & \multicolumn{3}{|c|}{ Overhead costs } \\
\hline & (1) & (2) & (3) \\
\hline \multirow[t]{2}{*}{ Bank concentration } & 0.056 & -0.081 & -0.057 \\
\hline & $(0.820)$ & $(0.735)$ & $(0.737)$ \\
\hline \multirow{2}{*}{ Bank size } & $* * *-0.133$ & $* * *-0.132$ & $* * *-0.132$ \\
\hline & $(0.021)$ & $(0.021)$ & $(0.021)$ \\
\hline \multirow[t]{2}{*}{ Liquidity } & 0.002 & -0.000 & -0.000 \\
\hline & $(0.003)$ & $(0.002)$ & $(0.002)$ \\
\hline \multirow[t]{2}{*}{ Bank equity } & -0.002 & 0.006 & 0.006 \\
\hline & $(0.006)$ & $(0.005)$ & $(0.005)$ \\
\hline \multirow{2}{*}{ Fee income } & $* * * 0.362$ & $* * * 0.373$ & $* * * 0.372$ \\
\hline & $(0.023)$ & $(0.022)$ & $(0.022)$ \\
\hline \multirow[t]{2}{*}{ Inflation } & $* 0.012$ & $* 0.012$ & *0.013 \\
\hline & $(0.007)$ & $(0.007)$ & $(0.007)$ \\
\hline \multirow[t]{2}{*}{ Property rights } & $* * *-0.564$ & $* * *-0.587$ & $* * *-0.584$ \\
\hline & $(0.205)$ & $(0.182)$ & $(0.200)$ \\
\hline \multirow[t]{2}{*}{ Fraction of entry denied } & 0.008 & - & - \\
\hline & $(0.739)$ & & \\
\hline Activity restrictions & - & $\begin{array}{r}0.142 \\
(0.276)\end{array}$ & - \\
\hline Banking freedom & - & - & $\begin{array}{r}-0.065 \\
(0.220)\end{array}$ \\
\hline R2-within & 0.210 & 0.212 & 0.212 \\
\hline R2-between & 0.525 & 0.517 & 0.515 \\
\hline No. observations & 1189 & 1343 & 1343 \\
\hline No. countries & 54 & 69 & 69 \\
\hline
\end{tabular}

Notes: Dependent variable is overhead costs over total average assets, average for the period 1995-99. All countrylevel variables are averages for the period 1995-99. All bank-specific independent variables are year 1995 data. For more details on the definition and source of the variables, see the Appendix. We use GLS with random country effects. A constant term was included, but is not reported. *, **,*** indicate significance levels of 10,5 , and 1 percent respectively. 
Table 12. Regression results controlling for bank risk, institutions and regulatory restrictions

\begin{tabular}{|c|c|c|c|c|c|c|c|c|c|}
\hline & (1) & (2) & (3) & (4) & $(5)$ & (6) & (7) & $(8)$ & (9) \\
\hline \multirow[t]{2}{*}{ Bank concentration } & $* * 2.814$ & 1.925 & $* 1.963$ & $* 1.827$ & 0.906 & 1.193 & 1.157 & 1.133 & 1.207 \\
\hline & $(1.122)$ & $(1.239)$ & $(1.037)$ & $(1.065)$ & $(1.052)$ & $(1.065)$ & (1.219) & $(1.040)$ & $(1.066)$ \\
\hline \multirow[t]{2}{*}{ Bank size } & $* * *-0.182$ & $* * *-0.180$ & $* * *-0.180$ & $* * *-0.178$ & $* * *-0.171$ & $* * *-0.171$ & $* * *-0.174$ & $* * *-0.171$ & $* * *-0.171$ \\
\hline & $(0.024)$ & $(0.024)$ & $(0.024)$ & $(0.024)$ & $(0.024)$ & $(0.024)$ & $(0.024)$ & $(0.024)$ & $(0.024)$ \\
\hline \multirow[t]{2}{*}{ Liquidity } & $* * *-0.018$ & $* * *-0.016$ & $* * *-0.019$ & $* * *-0.020$ & $* * *-0.020$ & $* * *-0.020$ & $* * *-0.017$ & $* * *-0.020$ & $* * *-0.020$ \\
\hline & $(0.003)$ & $(0.003)$ & $(0.003)$ & $(0.003)$ & $(0.003)$ & $(0.003)$ & $(0.003)$ & $(0.003)$ & $(0.003)$ \\
\hline \multirow[t]{2}{*}{ Bank equity } & $* * * 0.024$ & $* * 0.013$ & $* * * 0.022$ & $* * * 0.022$ & $* * * 0.023$ & $* * * 0.023$ & $* * 0.013$ & $* * * 0.023$ & $* * * 0.023$ \\
\hline & $(0.006)$ & $(0.006)$ & $(0.006)$ & $(0.006)$ & $(0.006)$ & $(0.006)$ & $(0.006)$ & $(0.006)$ & $(0.006)$ \\
\hline \multirow[t]{2}{*}{ Fee income } & -0.029 & $*_{-}-0.053$ & -0.019 & -0.023 & -0.025 & -0.025 & $* *_{-} 0.053$ & -0.024 & -0.025 \\
\hline & $(0.026)$ & $(0.026)$ & $(0.026)$ & $(0.026)$ & $(0.026)$ & $(0.026)$ & $(0.026)$ & $(0.026)$ & $(0.026)$ \\
\hline \multirow[t]{2}{*}{ Bank risk } & 0.001 & -0.075 & -0.020 & -0.023 & -0.029 & -0.028 & -0.075 & -0.027 & -0.028 \\
\hline & $(0.041)$ & $(0.051)$ & $(0.042)$ & $(0.042)$ & $(0.041)$ & $(0.042)$ & $(0.051)$ & $(0.042)$ & $(0.042)$ \\
\hline \multirow[t]{2}{*}{ Inflation } & - & $* * * 0.040$ & $* * * 0.036$ & $* * * 0.038$ & $* * * 0.025$ & $* * * 0.029$ & $* * * 0.029$ & $* * * 0.027$ & $* * * 0.029$ \\
\hline & & $(0.009)$ & $(0.009)$ & $(0.009)$ & $(0.009)$ & $(0.009)$ & $(0.010)$ & $(0.009)$ & $(0.009)$ \\
\hline \multirow[t]{2}{*}{ Fraction of entry denied } & 一 & $* * * 2.831$ & - & - & - & - & 1.616 & - & - \\
\hline & & $(1.065)$ & & & & & $(1.083)$ & & \\
\hline \multirow[t]{2}{*}{ Activity restrictions } & - & - & $* * * 1.006$ & - & - & - & - & 0.442 & - \\
\hline & & & $(0.376)$ & & & & & $(0.392)$ & \\
\hline \multirow[t]{2}{*}{ Banking freedom } & - & - & - & $* * *_{-} 0.778$ & - & - & - & - & $* * *-0.213$ \\
\hline & & & & $(0.281)$ & & & & & $(0.318)$ \\
\hline \multirow[t]{2}{*}{ Economic freedom } & - & - & - & - & $* * *-2.059$ & - & - & - & - \\
\hline & & & & & $(0.418)$ & & & & \\
\hline \multirow[t]{2}{*}{ Property rights } & 一 & - & - & - & - & $* * *-1.139$ & $* * *-1.115$ & $* * *-1.057$ & $* * *-1.045$ \\
\hline & & & & & & $(0.251)$ & (0.299) & $(0.255)$ & $(0.288)$ \\
\hline R2-within & 0.107 & 0.097 & 0.106 & 0.107 & 0.107 & 0.107 & 0.107 & 0.107 & 0.107 \\
\hline R2-between & 0.126 & 0.380 & 0.347 & 0.372 & 0.502 & 0.474 & 0.503 & 0.482 & 0.477 \\
\hline No. observations & 1372 & 1189 & 1344 & 1343 & 1343 & 1343 & 1189 & 1343 & 1343 \\
\hline No. countries & 71 & 54 & 70 & 69 & 69 & 69 & 54 & 69 & 69 \\
\hline
\end{tabular}

Notes: Dependent variable is net interest margin. All country-level variables are averages for the period 1995-99. All bank-specific variables are year 1995 data, except net interest margin for which we use averages for the period 1995-99. For more details on the definition and source of the variables, see the Appendix. We use GLS with random country effects. A constant term was included, but is not reported. *, **, *** indicate significance levels of 10 , 5 , and 1 percent respectively. 
Table 13. Regression results using country-level averages and controlling for institutions and regulatory restrictions

\begin{tabular}{|c|c|c|c|c|c|c|c|c|}
\hline & $(1)$ & $(2)$ & (3) & (4) & $(5)$ & $(6)$ & $(7)$ & $(8)$ \\
\hline \multirow[t]{2}{*}{ Bank concentration } & $* 2.417$ & $* * 2.474$ & $* 2.192$ & 1.318 & 1.538 & 1.442 & 1.499 & 1.536 \\
\hline & $(1.340)$ & $(1.161)$ & $(1.164)$ & $(1.081)$ & $(1.065)$ & $(1.221)$ & $(1.044)$ & $(1.068)$ \\
\hline Inflation & $(0.012)$ & $(0.012)$ & $(0.011)$ & $(0.008)$ & $(0.008)$ & $(0.009)$ & $(0.008)$ & $(0.008)$ \\
\hline \multirow[t]{2}{*}{ Fraction of entry denied } & 1.805 & - & - & - & - & 0.523 & - & - \\
\hline & $(1.466)$ & & & & & $(1.444)$ & & \\
\hline \multirow[t]{2}{*}{ Activity restrictions } & - & $* * 0.989$ & - & - & - & - & 0.315 & - \\
\hline & & $(0.410)$ & & & & & $(0.364)$ & \\
\hline \multirow[t]{2}{*}{ Banking freedom } & - & - & $* * *_{-} 0.810$ & - & - & - & - & -0.189 \\
\hline & & & $(0.267)$ & & & & & $(0.281)$ \\
\hline \multirow[t]{2}{*}{ Economic freedom } & - & - & - & $* * *-2.028$ & - & - & - & - \\
\hline & & & & $(0.467)$ & & & & \\
\hline \multirow[t]{2}{*}{ Property rights } & - & - & - & - & $* * *-1.164$ & $* * *-1.181$ & $* * *-1.102$ & $* * *-1.080$ \\
\hline & & & & & $(0.285)$ & $(0.337)$ & $(0.288)$ & $(0.298)$ \\
\hline
\end{tabular}

Notes: Dependent variable is net interest margin averaged across banks in each country. All country variables are averages for the period 1995-99. Net interest margins are country-averages for the period 1995-99. For more details on the definition and source of the variables, see the Appendix. We report OLS estimates with heteroskedasticity-consistent standard errors. A constant term was included, but is not reported. *, **, *** indicate significance levels of 10,5 , and 1 percent respectively. 
Table 14. Regression results controlling for bank market share, institutions and regulatory restrictions

\begin{tabular}{|c|c|c|c|c|c|c|c|c|c|}
\hline & $(1)$ & (2) & (3) & (4) & $(5)$ & $(6)$ & $(7)$ & $(8)$ & $(9)$ \\
\hline \multirow[t]{2}{*}{ Bank concentration } & $* 2.004$ & 1.085 & 1.172 & 1.225 & 0.441 & 0.716 & 0.576 & 0.643 & 0.740 \\
\hline & $(1.057)$ & $(1.069)$ & $(0.944)$ & $(0.989)$ & $(0.979)$ & $(0.988)$ & $(1.077)$ & $(0.959)$ & $(0.996)$ \\
\hline \multirow[t]{2}{*}{ Market share } & $* * * 1.583$ & $* * * 1.677$ & $* * * 1.621$ & $* * 1.336$ & $* * 1.171$ & $* * 1.164$ & $* * 1.347$ & $* * 1.195$ & $* * 1.142$ \\
\hline & $(0.577)$ & $(0.644)$ & $(0.570)$ & $(0.576)$ & $(0.573)$ & $(0.575)$ & $(0.645)$ & $(0.574)$ & $(0.575)$ \\
\hline \multirow[t]{2}{*}{ Bank size } & $* * *-0.220$ & $* * *-0.214$ & $* * *-0.219$ & $* * *_{-} 0.210$ & $* * *-0.198$ & $* * *-0.197$ & $* * *_{-} 0.199$ & $* * *-0.199$ & $* * *-0.197$ \\
\hline & $(0.027)$ & $(0.027)$ & $(0.027)$ & $(0.027)$ & $(0.027)$ & $(0.027)$ & $(0.027)$ & $(0.027)$ & $(0.027)$ \\
\hline \multirow[t]{2}{*}{ Liquidity } & $* * *-0.018$ & $* * *-0.015$ & $* * *-0.019$ & $* * *-0.019$ & $* * *-0.020$ & $* * *_{-}-0.020$ & $* * *-0.016$ & $* * *-0.019$ & $* * *-0.020$ \\
\hline & $(0.003)$ & $(0.003)$ & $(0.003)$ & $(0.003)$ & $(0.003)$ & $(0.003)$ & $(0.003)$ & $(0.003)$ & $(0.003)$ \\
\hline \multirow[t]{2}{*}{ Bank equity } & $* * * 0.023$ & $* 0.012$ & $* * * 0.021$ & $* * * 0.022$ & $* * * 0.023$ & $* * * 0.022$ & $* * * 0.013$ & $* * * 0.022$ & $* * * 0.022$ \\
\hline & $(0.006)$ & $(0.007)$ & $(0.006)$ & $(0.006)$ & $(0.006)$ & $(0.006)$ & $(0.006)$ & $(0.006)$ & $(0.006)$ \\
\hline \multirow[t]{2}{*}{ Fee income } & -0.026 & $* *-0.054$ & -0.017 & -0.022 & -0.026 & -0.025 & $* *_{-} 0.055$ & -0.023 & -0.025 \\
\hline & $(0.026)$ & $(0.026)$ & $(0.026)$ & $(0.026)$ & $(0.026)$ & $(0.026)$ & $(0.026)$ & $(0.026)$ & $(0.026)$ \\
\hline \multirow[t]{2}{*}{ Inflation } & - & $* * * 0.040$ & $* * * 0.036$ & $* * * 0.038$ & $* * * 0.025$ & $* * * 0.029$ & $* * * 0.029$ & $* * * 0.028$ & $* * * 0.029$ \\
\hline & & $(0.008)$ & $(0.008)$ & $(0.008)$ & $(0.008)$ & $(0.008)$ & $(0.008)$ & $(0.008)$ & $(0.008)$ \\
\hline \multirow[t]{2}{*}{ Fraction of entry denied } & - & $* * * 2.380$ & - & - & - & - & 1.288 & - & - \\
\hline & & $(0.891)$ & & & & & $(0.932)$ & & \\
\hline \multirow[t]{2}{*}{ Activity restrictions } & - & - & $* * * 0.948$ & - & - & - & - & 0.458 & - \\
\hline & & & $(0.329)$ & & & & & $(0.349)$ & \\
\hline \multirow[t]{2}{*}{ Banking freedom } & 一 & - & - & $* * *-0.712$ & - & - & - & - & -0.195 \\
\hline & & & & $(0.254)$ & & & & & $(0.263)$ \\
\hline \multirow[t]{2}{*}{ Economic freedom } & - & - & - & - & $* * *-1.931$ & - & - & - & - \\
\hline & & & & & $(0.382)$ & & & & \\
\hline \multirow[t]{2}{*}{ Property rights } & - & - & - & - & - & $* * *-1.065$ & $* * *-1.046$ & $* * *-0.978$ & $* * *-0.981$ \\
\hline & & & & & & $(0.229)$ & $(0.260)$ & $(0.231)$ & $(0.263)$ \\
\hline R2-within & 0.106 & 0.095 & 0.105 & 0.106 & 0.107 & 0.107 & 0.096 & 0.107 & 0.107 \\
\hline R2-between & 0.220 & 0.430 & 0.414 & 0.415 & 0.528 & 0.501 & 0.527 & 0.510 & 0.503 \\
\hline No. observations & 1372 & 1189 & 1344 & 1343 & 1343 & 1343 & 1189 & 1343 & 1343 \\
\hline No. countries & 71 & 54 & 70 & 69 & 69 & 69 & 54 & 69 & 69 \\
\hline
\end{tabular}

Notes: Dependent variable is net interest margin. All country-level variables are averages for the period 1995-99. All bank-specific variables are year 1995 data, except net interest margin for which we use averages for the period 1995-99. For more details on the definition and source of the variables, see the Appendix. We use GLS with random country effects. A constant term was included, but is not reported. *, **, *** indicate significance levels of 10 , 5 , and 1 percent respectively. 


\section{Appendix. Description of Variables and Data Sources}

\section{Variable name}

\section{Description and source}

Bank market structure

Number of Banks ${ }^{1}$

Bank concentration ${ }^{2}$

Bank concentration (Top-5) ${ }^{2}$

Bank concentration (All) ${ }^{2}$

Bank concentration (Deposits)

Ban-specific variables:

Net interest margin ${ }^{2}$

Bank size $e^{2}$

Bank Equity $^{2}$

Liquidity $^{2}$

Overhead $^{2}$

Fee income ${ }^{2}$
Number of commercial banks in existence as of end-1999 (Survey of Bank Regulation and Supervision question 1.2).

A measure of the degree of concentration in the banking industry, calculated as the fraction of assets held by the three largest commercial banks in each country, average over the period 1995-99.

A measure of the degree of concentration in the banking industry, calculated as the fraction of assets held by the five largest commercial banks in each country, average over the period 1995-99.

A measure of the degree of concentration in the banking industry, calculated as the fraction of assets held by the three largest commercial banks, savings banks, cooperative banks and/or non-bank credit institutions in each country, average over the period 1995-99.

A measure of the degree of concentration in the banking industry, calculated as the fraction of deposits held by the five largest commercial banks in each country as of end-1999.

Interest income minus interest expense divided by interest-bearing assets, average over the period 1995-99.

Logarithm of total individual bank assets in millions of U.S. dollars, year 1995.

Bank equity divided by total assets, year 1995 .

Liquid bank assets divided by total bank assets, year 1995.

Overhead costs divided by total assets, year 1995.

Other operating income divided by total assets, year 1995. 
Appendix (cont.)

\section{Variable name}

Bank risk $^{2}$

Market share

Regulatory restrictions:

Fraction of Entry Denied

Activity Restrictions ${ }^{1}$

Banking freedom ${ }^{3}$

Reserve requirements ${ }^{1}$

Ownership:

State ownership ${ }^{1}$

Foreign ownership $^{1}$

Institutional environment:

Economic freedom ${ }^{3}$

\section{Description and source}

Standard deviation of the return on average assets over the period 1995-99.

Individual bank assets over total commercial bank assets as reported by Bankscope, year 1995.

A measure of the number of entry applications denied as a fraction of the number of applications received from domestic and foreign entities (ratio of Survey of Bank Regulation and Supervision questions 1.9.1 and 1.10.1 to 1.9 and 1.10).

A measure of a bank's ability to engage in the businesses of securities underwriting, insurance, and real estate, and of the regulatory restrictiveness of banks to own shares in non-financial firms (sum of Survey of Bank Regulation and Supervision questions 4.1 through 4.4).

An indicator of banking freedom (ranging from 1 to 5), averaged over 1995-99 period. Greater values signify more freedom. Calculated as 6 minus the banking freedom index of the Heritage Foundation.

Takes value of one if banks are required to hold either liquidity reserves or any reserves whatsoever on deposits at the Central Bank? (Based on question 7.3 of Survey of Bank Regulation and Supervision).

A measure of the degree of government ownership of banks, measured as the fraction of the banking system's assets that is in banks that are 50\% or more government owned (Question 3.7 in the Survey of Bank Regulation and Supervision).

A measure of the degree of foreign ownership of banks, measured as the fraction of the banking system's assets that is in banks that are 50\% or more foreign owned (Question 3.8 in the Survey of Bank Regulation and Supervision).

An indicator of economic freedom (ranging from 1 to 5), averaged over 1995-99 period. Greater values signify more freedom. Calculated as 6 minus the economic freedom index of the Heritage Foundation. 


\section{Appendix (cont.)}

\section{Variable name}

\section{Description and source}

Property rights ${ }^{3}$

KKZ Institution index

GDP per capita ${ }^{4}$

Other variables.

Total traded value ${ }^{4}$

Inflation $^{4}$

GDP growth ${ }^{4}$
An indicator of the protection of private property rights (ranging from 1 to 5), averaged over 1995-99 period. Greater values signify better protection of property rights). Calculated as 6 minus the property freedom index of the Heritage Foundation.

An indicator of the quality of institutional development in the country. Calculated as the average of six indicators: voice and accountability, political stability, government effectiveness, regulatory quality, rule of law, and control of corruption. Average for the period 1998. Source: Kaufmann, Kraay, Zoido-Lobaton (2001).

GDP per capita expressed in thousands of 1995 U.S. dollars, averaged over the period 1995-99.

${ }^{1}$ Source: Barth, Caprio, and Levine (2001b). Data available at: www.worldbank.org/research/projects/bank_regulation.htm

${ }^{2}$ Source: Fitch IBCA's Bankscope Database

${ }^{3}$ Source: Economic Freedom Index of the Heritage Foundation

${ }^{4}$ Source: World Development Indicators, World Bank 